Published in "Journal of Hydrology 510: 35-48, 2013"

which should be cited to refer to this work.

\title{
High uncertainty in 21st century runoff projections from glacierized basins
}

\author{
Matthias Huss $^{\mathrm{a}, \mathrm{b}, *}$, Michael Zemp ${ }^{\mathrm{b}}$, Philip C. Joerg ${ }^{\mathrm{b}}$, Nadine Salzmann ${ }^{\mathrm{a}}$ \\ ${ }^{a}$ Department of Geosciences, University of Fribourg, $\mathrm{CH}-1700$ Fribourg, Switzerland \\ ${ }^{\mathrm{b}}$ Department of Geography, University of Zurich, $\mathrm{CH}-8057$ Zurich, Switzerland
}

\begin{abstract}
Glacier response to a changing climate and its impact on runoff is understood in general terms, but model-based projections are affected by considerable uncertainties. They originate from the driving climate model, input data quality, and simplifications in the glacio-hydrological model and hamper the reliability of the simulations. Here, an integrative assessment of the uncertainty in 21st century glacier runoff is provided based on experiments using the Glacier Evolution Runoff Model (GERM) applied to the catchment of Findelengletscher, Switzerland. GERM is calibrated and validated in a multi-objective approach and is run using nine Regional Climate Models (RCMs) until 2100. Among others, the hydrological impacts of the RCM downscaling procedure, the winter snow accumulation, the surface albedo and the calculation of ice melt and glacier retreat are investigated. All experiments indicate rapid glacier wastage and a transient runoff increase followed by reduced melt season discharge. However, major uncertainties in, e.g., glacier area loss $(-100 \%$ to $-63 \%)$ and the change in annual runoff ( $-57 \%$ to $+25 \%$ relative to today) by 2100 are found. The impact of model assumptions on changes in August runoff is even higher ( $-94 \%$ to $-5 \%$ ). The spread in RCM results accounts for $20-50 \%$ of the overall uncertainty in modeled discharge. Initial ice thickness, the amount and spatial distribution of winter snow and the glacier retreat model have the largest effect on the projections, whereas the RCM downscaling procedure, calibration data quality and the melt model (energy balance vs. degree-day approach) are of secondary importance.
\end{abstract}

\section{Introduction}

Ongoing and future climate change has major impact on alpine environments (e.g., Beniston, 2003). The potential loss of a substantial fraction of glacier ice volume until the end of this century will significantly alter the runoff characteristics of mountainous drainage basins (e.g., Braun et al., 2000; Barnett et al., 2005; Huss, 2011). Due to a seasonal shortage of water supply, downstream impacts of changes in the cryosphere might be considerable in terms of irrigation for agriculture, hydropower production, river transportation and ecology (Xu et al., 2009; Immerzeel et al., 2010; Kaser et al., 2010; Viviroli et al., 2011).

Numerous model studies for a wide range of climatic settings have been performed, estimating future trends in the hydrology of glacierized basins (e.g., Juen et al., 2007; Stahl et al., 2008; Weber et al., 2010; Hagg et al., 2013; Bavay et al., 2013; Ragettli et al., 2013). As a robust result, a shift in the runoff regime and a decrease in melting season discharge is found on the long run. However, an

\footnotetext{
* Corresponding author at: Department of Geosciences, University of Fribourg CH-1700 Fribourg, Switzerland. Tel.: +4126300 9029.

E-mail address: matthias.huss@unifr.ch (M. Huss).
}

integrative uncertainty assessment of modeled future runoff from high-mountain catchments has not been performed to date.

The uncertainty in projected runoff is the combined effect of the spread in climate model results, the downscaling procedure, input data quality, as well as simplifications and poorly understood feedbacks in the modeling of glacier change and runoff. Although the individual uncertainties might cancel each other out, some parameterizations in the impact models might lead to a systematic overor underestimation of future runoff, and thus require a careful evaluation. Knowledge about the integrated uncertainties is vital for making runoff projections useful in terms of adaptations in the water resource management.

Several individual components of the uncertainty in glacier runoff projections have recently been assessed. The impact of differences in air temperature and precipitation trends projected by Regional Climate Models (RCMs) or Global Circulation Models (GCMs) on the runoff regime of glacierized catchments was addressed in different regions (e.g., Stahl et al., 2008; Farinotti et al., 2012; Lutz et al., 2013; Ragettli et al., 2013). Dedicated studies have investigated the effect of climate model data downscaling procedures on calculated glacier mass balance (e.g., Radić and Hock, 2006; Kotlarski et al., 2010; Salzmann et al., 2012), and the 
field data requirements for an unambiguous calibration of hydrological models (Konz and Seibert, 2010; Schaefli and Huss, 2011). It has been recognized that the estimate of the initial glacier ice volume (Gabbi et al., 2012), and the approach to calculate glacier geometry change have a strong impact on calculated future glacier area and runoff (Huss et al., 2010b; Linsbauer et al., 2013). Many studies have focused on uncertainties in modeling of snow and ice melt based on the surface energy balance or temperature-index models (e.g., Klok and Oerlemans, 2004; Hock, 2005; Pellicciotti et al., 2005; Kobierska et al., 2013). Other factors such as the effect of the spatial snow accumulation distribution, and changes in debris-covered glacier surfaces on modeled discharge have not yet been specifically addressed by glacio-hydrological studies to our knowledge.

This paper aims at a detailed assessment of the major uncertainties in the modeling of future runoff from glacierized drainage basins, and quantifies potential uncertainty ranges based on an extensive set of model experiments. This allows identifying the factors and processes that are the least constrained by state-of-the-art glacio-hydrological model approaches and are most influential for the overall uncertainty in 21 st century runoff projections. Our study is focused on the high-alpine catchment of Findelengletscher, Swiss Alps, for which a wealth of data on glacier mass balance and discharge over several decades is available. The basin thus represents an ideal test site for this comprehensive modeling study.

\section{Study site and data}

\subsection{Geographical setting}

Findelengletscher is a large temperate valley glacier in the southern Swiss Alps ( $\left.46^{\circ} 00^{\prime} \mathrm{N}, 7^{\circ} 52^{\prime} \mathrm{E}\right)$. The region is characterized by glacier equilibrium line altitudes of around $3300 \mathrm{~m}$ a.s.l., being among the highest in the Alps (Maisch et al., 2000). The catchment of the hydrological station ranges from 2484 to $4173 \mathrm{~m}$ a.s.l., and has an area of $21.2 \mathrm{~km}^{2}$ (Fig. 1). The basin is located in the headwa- ters of the Rhone River and was $74 \%$ glacierized in 2010 , leading to a distinctly glacial runoff regime. Findelengletscher $\left(13.0 \mathrm{~km}^{2}\right.$ in 2010) occupies the largest part of the watershed. Adlergletscher $\left(2.0 \mathrm{~km}^{2}\right)$ and a few smaller glaciers make up for the rest of the glacierization (Fig. 1).

\subsection{Studies on Findelengletscher}

Over the last years, considerable knowledge about glaciological and hydrological processes and changes in the basin of Findelengletscher has been accumulated representing a starting point for this study. Machguth et al. (2006a) and Sold et al. (2013) investigated the spatial distribution of winter snow on Findelengletscher. Long-term series of glacier mass balance since 1900 were derived by Huss et al. (2010a). Several authors have addressed the future hydrology of the catchment. Farinotti et al. (2012) calculated glacier retreat and runoff over the 21st century using ten RCMs of the ENSEMBLES project (van der Linden and Mitchell, 2009). Uhlmann et al. (2013a) and Uhlmann et al. (2013b) calibrated a hydrological model to discharge data and performed a model run until 2100 using results of one RCM from the PRUDENCE project (Christensen and Christensen, 2007).

\subsection{Field data}

A mass balance monitoring program is maintained on Findelenand Adlergletscher since 2004 (Machguth, 2008). Extrapolation of mass balance measured at a network of 13 stakes and 2 snow pits (Fig. 1) over the glacier yields the annual mass budget of Findelengletscher, as well as the altitudinal distribution of melt and accumulation. Winter balance is determined since 2009 by $5-10$ snow pits and 400-700 manual snow probings per survey, distributed over the entire elevation range. The monitoring of snow accumulation distribution is further supported by helicopter-borne ground-penetrating radar (GPR) since 2010 providing snow depth on several tens of kilometers of continuous tracks (Sold et al., 2013).

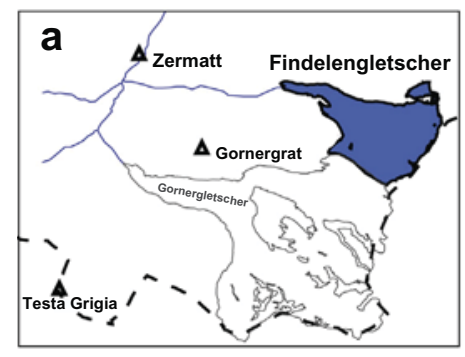

Elevation change 2005-2010 (m)

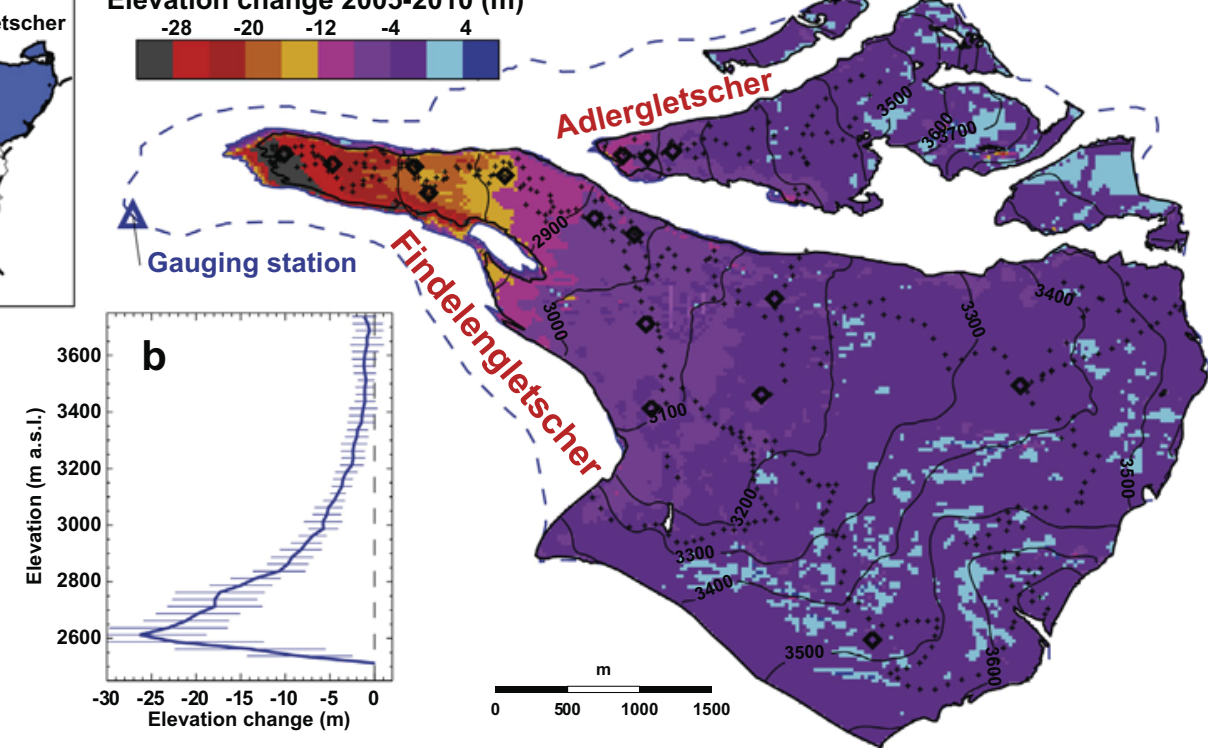

Fig. 1. Recent changes in the geometry of Findelengletscher. Colours show glacier surface elevation changes between October 2005 and September 2010 based on a comparison of two DEMs (Joerg et al., 2012). Stakes and snow pits for the measurement of annual mass balance are depicted with diamonds, snow probings realized in April 2010 are indicated (crosses). The location of weather stations around the study site is given in inset (a). Inset (b) provides the altitudinal distribution of observed surface elevation change. The variability ( \pm 2 standard deviations) within each band is shown. (For interpretation of the references to colour in this figure legend, the reader is referred to the web version of this article.) 
Five Digital Elevation Models (DEMs) documenting glacier surface elevation changes are available for Findelen- and Adlergletscher. DEMs for 1982 and 2007 with a spatial resolution of $25 \mathrm{~m}$ and an estimated accuracy of $\pm 0.5 \mathrm{~m}$ were derived based on airborne photogrammetry (Bauder et al., 2007). For 2005, 2009 and 2010, high-resolution Light Detection And Ranging (LiDAR) DEMs with a random error of $<0.01 \mathrm{~m}$ were established (Joerg et al., 2012). Glacier outlines were mapped for each DEM (Fig. 1). DEM differencing allows the calculation of ice volume changes. A LiDAR DEM is also available for April 2010 (Joerg et al., 2012). By comparing this terrain model with the DEM from October 2009 and applying a correction for submergence and emergence of the glacier surface over the winter season, a fully distributed map of snow depth on a $1 \times 1 \mathrm{~m}$ grid over the entire glacier was derived (Sold et al., 2013).

Glacier ice thickness and volume was determined based on a combination of different Ground Penetrating Radar (GPR) measurement campaigns. Two profiles with a low-frequency helicopter-borne GPR device were acquired for the center of the glacier in 2008 (Farinotti et al., 2009). In March 2012, ground-based GPR measurements on the glacier tongue, and about $30 \mathrm{~km}$ of longitudinal and cross-glacier tracks were realized with helicopter-borne GPR. Whereas the ablation area is well covered with measurements, bedrock reflections were partly weak in the accumulation area. Therefore, an approach to invert ice thickness from surface topography based on the principles of flow dynamics (Huss and Farinotti, 2012) was first calibrated to the observations and then used as complementary information for regions with an insufficient number of direct measurements (about $50 \%$ of the glacier surface). The combined thickness map yields a maximum ice depth of $220 \mathrm{~m}$, and a total volume of $1.26 \mathrm{~km}^{3}$ in the drainage basin. Local ice thickness uncertainty is estimated as $\pm 10 \%$ for regions with GPR data, and $\pm 25 \%$ for unmeasured regions.

Continuous discharge measurements recorded by Grande Dixence SA are available for 1962-2010 at daily resolution. The gauging station is located at a distance of $1 \mathrm{~km}$ from the present glacier terminus (Fig. 1). There are no runoff data during the winter months (i.e. between November and April/May) for most years. Hence, we do not use annual runoff volumes for validation, although discharge is normally small during wintertime. For the summer months, data quality is high with only very few data gaps.

Daily mean air temperature, global incoming short-wave radiation and precipitation are available from a MeteoSwiss weather station at Zermatt ( $1638 \mathrm{~m}$ a.s.l., $6 \mathrm{~km}$ from glacier terminus). The data cover the period 1982-2012. In addition, daily air temperature for 1990-2008 from Gornergrat (3130 m a.s.l.) at a distance of $4 \mathrm{~km}$ from Findelengletscher, and Testa Grigia (3479 m a.s.l., $10 \mathrm{~km}, 1951-2000$ ) are available (Fig. 1).

\subsection{Climate scenarios}

Scenarios of future climate change are obtained from the project $\mathrm{CH} 2011$ (e.g., Bosshard et al., 2011) that presents an analysis of results of the ENSEMBLES climate model runs (van der Linden and Mitchell, 2009). ENSEMBLES RCMs are driven by different GCMs (Table 1) that are forced by the SRES A1B emission scenario (Nakicenovic et al., 2000). The A1B emission scenario represents an evolution close to the median of other storylines and features a rapid economic growth as well as a balanced use of fossil and nonfossil fuels. The changes in air temperature and precipitation used in this study are based on the 'delta change' approach (see e.g., Hay et al., 2000; Salzmann et al., 2007) and have been evaluated by Bosshard et al. (2011) for the grid points around Findelengletscher for ten RCMs. The 'delta change' approach expresses the effect of climate change between two periods in terms of the difference in the mean of a given variable. The periods have the same length
Table 1

Regional climate scenarios of the ENSEMBLES project with the responsible institution (Inst.) and abbreviations for the GCMs and the RCMs used. Projected changes in mean winter (November-April) and summer (May-October) air temperature (in ${ }^{\circ} \mathrm{C}$ ), $\Delta T_{\mathrm{w}}$ and $\Delta T_{\mathrm{s}}$, and precipitation (in \%), $\Delta P_{\mathrm{w}}$ and $\Delta P_{\mathrm{s}}$, for Findelengletscher in 2070-2099 are given relative to 1980-2009. The median scenario is written in bold face, and two extreme scenarios in italic.

\begin{tabular}{lllllrr}
\hline Inst. & GCM & RCM & $\Delta T_{\mathrm{w}}$ & $\Delta T_{\mathrm{s}}$ & $\Delta P_{\mathrm{w}}$ & \multicolumn{1}{c}{$\Delta P_{\mathrm{s}}$} \\
\hline MPI & ECHAM5 & REMO & 3.69 & 4.04 & +6 & -10 \\
SMHI & ECHAM5 & RCA & 3.69 & 4.15 & +3 & -16 \\
KNMI & ECHAM5 & RACMO & 2.82 & 4.22 & +4 & -16 \\
ICTP & ECHAM5 & REGCM & 2.69 & 3.32 & +10 & -10 \\
ETHZ & HadCM3Q0 & CLM & 3.51 & 4.60 & +6 & +2 \\
HC & HadCM3Q0 & HadRM3Q0 & 3.31 & 5.16 & +2 & -16 \\
SMHI & HadCM3Q3 & RCA & 3.69 & 3.43 & +18 & -10 \\
CNRM & ARPEGE & ALADIN & 2.83 & 4.09 & -11 & 0 \\
SMHI & BCM & RCA & 2.23 & 2.79 & -11 & -11 \\
\hline
\end{tabular}

(30 years) and are divided into a reference period (1980-2009) and three scenario periods (2021-2050/2045-2074/2070-2099). Changes in daily mean air temperature and precipitation between the reference and the scenario period are aggregated to monthly values. Note that temperature changes are additive, and precipitation changes are multiplicative, both relative to the period 1980 2009.

All RCM results prescribe a significant increase in air temperature (Table 1). For the period 2070-2099, changes in annual temperature relative to $1980-2009$ are between +2.5 and $+4.2{ }^{\circ} \mathrm{C}$. Expected trends in annual precipitation are minor and inconsistent between the RCMs. Temperature increase in summer is projected to be largest by all models $\left(+0.94{ }^{\circ} \mathrm{C}\right.$ above the annual average), and most RCMs indicate increased winter precipitation and a reduction in summer (Table 1). From the ten ENSEMBLES RCMs we select a median scenario that is henceforth used as a reference climate evolution (MPI_ECHAM5_REMO), and two extreme scenarios providing a lower bound (SMHI_BCM_RCA) and an upper bound (HC_HadCM3Q0_HadRM3Q0) of expected climate change. We completely exclude results from the DMI_ECHAM5_HIRHAM model in our study. Close inspection of the raw results of this RCM indicated the possibility of model artifacts close to the study region. As peaks in air temperature seemed to be cut off for the grid cells close to Findelengletscher, unrealistically small increases in summer temperatures in comparison to all other RCMs were evident.

\section{Methods}

\subsection{Glacier model}

Glacier mass balance, retreat and runoff is calculated using the Glacier Evolution Runoff Model (GERM, Huss et al., 2008). This glacio-hydrological model is designed to calculate past and future runoff from glacierized drainage basins and includes components for snow accumulation distribution, snow and ice melt, 3D glacier geometry change, evapotranspiration, and runoff routing. A detailed description of the model components is given in Huss et al. (2008); Huss et al., 2010b and Farinotti et al., 2012. Hereafter, the most important model parameterizations are briefly described and further developments of the original model are highlighted. GERM is run on a regular $25 \mathrm{~m}$ grid for the drainage basin of Findelengletscher.

The model is driven by daily mean temperature, global radiation and precipitation recorded at Zermatt. In order to reduce uncertainties due to extrapolation with elevation, measured temperatures are shifted to the Median Elevation (ME, 3305 m a.s.1.) of the catchment by using observed monthly temperature gradients between Zermatt, and the summit stations Gornergrat and 
Testa Grigia (Fig. 1). Temperatures for time step $t$ are then extrapolated to every gridcell $(x, y)$ by assuming an annually constant lapse rate $d T / d z$ as

$T(x, y, t)=T_{\mathrm{ME}}(t)+\left(z(x, y)-z_{\mathrm{ME}}\right) \cdot d T / d z$.

Snow accumulation $C$ (in water equivalent) is calculated based on the measured precipitation $P_{Z}(t)$ at Zermatt occurring at temperatures $T(x, y, t)<T_{\mathrm{thr}}$ as

$C(x, y, t)=P_{Z}(t) \cdot c_{\text {prec }} \cdot D(x, y)$.

$T_{\text {thr }}$ is the threshold temperature between solid and liquid precipitation with a linear transition range of $\pm 1{ }^{\circ} \mathrm{C}$. The factor $c_{\text {prec }}$ allows the adjustment of measured precipitation sums to the drainage basin and accounts for gauge undercatch. Spatial variations in accumulation due to preferential snow deposition and wind-driven snow redistribution are taken into account by using a snow distribution multiplier $D(x, y)$ (Tarboton et al., 1995; Farinotti et al., 2010). $D(x, y)$ is specifically derived for Findelengletscher from direct observations of accumulation variability (Sold et al., 2013) combined with small-scale terrain characteristics and has values between 0 and 2 .

Snow and ice melt is calculated based on a simplified formulation of the energy balance equation proposed by Oerlemans (2001). The energy available for melt $Q_{M}=Q_{M}(x, y, t)$ is obtained by

$Q_{M}=(1-\alpha) \cdot G+k_{0}+k_{1} T$

where $\alpha=\alpha(x, y, t)$ is the local surface albedo at day $t$, and $G=G(x, y, t)$ in $\mathrm{W} \mathrm{m}^{-2}$ is the global incoming short-wave radiation. $k_{0}+k_{1} T$ is the sum of the long-wave radiation balance and the turbulent heat exchange linearized around the melting point (Oerlemans, 2001; Machguth et al., 2006b), with $k_{0}$ and $k_{1}$ as constant parameters, and $T$ the air temperature. As no continuous and homogeneous radiation measurements are available for the drainage ba$\sin , G$ is computed as

$G(x, y, t)=r(t) \cdot I_{\mathrm{pot}}(x, y, t)$,

with $I_{\text {pot }}$ the potential clear-sky solar radiation and $r(t)$ the daily ratio of observed to potential global radiation derived from the measurements at Zermatt. If $Q_{M}$ is greater than zero, the melt rate is obtained with the latent heat of fusion.

The temporal change in snow albedo $\alpha_{\text {snow }}$ is calculated after Oerlemans and Knap (1998) as

$\alpha_{\text {snow }}=\alpha_{\text {firn }}+\left(\alpha_{\text {snow }, 0}-\alpha_{\text {firn }}\right) \exp \left(\frac{d}{d^{*}}\right)$,

where we assume $\alpha_{\text {firn }}=0.5$ the albedo of firn, and $\alpha_{\text {snow } .0}=0.92$ the albedo of fresh snow (e.g., Cuffey and Paterson, 2010). $d$ is the number of days since the last snowfall and $d^{*}=22$ is a typical time scale (Oerlemans and Knap, 1998).

Glacier geometry change occurring in response to surface mass balance forcing is calculated based of the $\Delta \mathrm{h}$-parameterization (Huss et al., 2010b). With a simple empirical function, glacier surface elevation change is related to the altitudinal range of the glacier yielding maximum ice thickness changes at the glacier snout and small variations in the accumulation area. Prescribing mass conservation, the annual change in ice volume calculated with the mass balance model is distributed across the glacier surface using the non-dimensional elevation change pattern as observed in 1982-2010. The glacier disappears where ice thickness becomes smaller than zero. This straight-forward approach has been shown to yield results for 21st century glacier front variations that compare well to higher-order 3D ice flow modeling (Huss et al., 2010b).

\subsection{Daily meteorological series until 2100}

We generate transient series of future air temperature and precipitation from the monthly 'delta changes' computed by Bosshard et al. (2011) based on RCM results for three 30-year periods in the 21 st century. We first interpolate the monthly changes linearly between the center points of the periods (i.e. 1995, 2035, 2060 and 2085). After 2085, changes are extrapolated with the rate of 2060-2085. This provides continuous series of monthly mean temperature and precipitation for the period of future modeling (2013-2100). Assuming no change in daily meteorological variability, we randomly select years in the period 1982-2012 from the Zermatt station, and shift the monthly means of the measured meteorological variables to the scenario results (see also Huss et al., 2008). Applying this method, continuous daily series of temperature and precipitation for 2013-2100 are obtained that preserve the characteristic meteorological variability of the observed series used for model calibration, and include trends in monthly climatic changes as prescribed by the RCMs. Finally, ten model runs for each scenario simulation are performed in order to filter variability originating from the characteristics of the randomly selected years used for the generation of the future daily meteorological series.

We do not consider global radiation data given by the RCMs for the future modeling and use monthly means of $r(t)$ (Eq. (4)) as observed in the past for the model runs until 2100. Climate models generally have a limited skill in reproducing changes in global radiation and cloudiness (e.g., Wild and Schmucki, 2011). Furthermore, evaluation of RCM-based global radiation series for the study region showed neither significant nor consistent trends between 1950-2100 for the summer months.

\subsection{Model calibration and validation}

GERM is calibrated and validated in a multi-objective approach over 1982-2012. For this period, various field measurements allow us to constrain all components of the water balance in the drainage basin of Findelengletscher. The measured glacier volume change 1982-2007 is chosen as the main calibration data source. This observation accurately integrates the glacier mass budget at a multidecadal scale. Correctly capturing the dynamics of long-term ice storage change is most critical to assessing future catchment water balance. In addition, winter snow observations are used for calibration allowing us to unambiguously separate accumulation and melt components of total discharge. Observed glacier front variations, annual mass balance measurements and monthly/daily runoff are used for model validation. Model parameters are calibrated manually due to constraints with computation time and the need for consistency between parameter sets obtained for the different experiments (see chapter 3.4).

The catchment precipitation is calibrated to match spatially distributed snow accumulation measured in five years using the factor $c_{\text {prec }}$ (Eq. (2)). The parameters of the energy balance model, $k_{0}$ and $k_{1}$, are tuned to the long-term ice volume change. The albedo of bare glacier ice is set to $\alpha_{\text {ice }}=0.25$ (e.g., Klok et al., 2003). $T_{\text {thres }}=1.5^{\circ} \mathrm{C}$ is based on literature values (Rohrer, 1989). The temperature lapse rate $d T / d z=-0.0065^{\circ} \mathrm{C} \mathrm{m}^{-1}$ was derived from stations in the vicinity of Findelengletscher (inset in Fig. 1) as a mean for the melting season (June-August). The adjusted parameters of GERM are given in Table 2 .

GERM is initialized with the glacier geometry of 1982 and is run until 2012 using meteorological data from Zermatt. The change in glacier length, area and ice surface elevation is accurately reproduced over the 30 -year period (Fig. 2). The retreat of the terminus of Findelengletscher since 1982 is captured, as well as the detachment of Adlergletscher from the main glacier branch. Calculated 
Table 2

Important parameters of the melt-accumulation model for the reference calibration.

\begin{tabular}{lcl}
\hline Parameter & Value & Unit \\
\hline$k_{0}$ & -33.5 & $\mathrm{~W} \mathrm{~m}^{-2}$ \\
$k_{1}$ & 12.0 & $\mathrm{~W} \mathrm{~m}^{-2}{ }^{\circ} \mathrm{C}^{-1}$ \\
$\alpha_{\text {ice }}$ & 0.25 & - \\
$\alpha_{\text {snow }, 0}$ & 0.92 & - \\
$\alpha_{\text {firn }}$ & 0.50 & - \\
$c_{\text {prec }}$ & 4.0 & - \\
$T_{\text {thres }}$ & 1.5 & ${ }^{\circ} \mathrm{C}$ \\
$\mathrm{d} T / \mathrm{d} z$ & -0.0065 & ${ }^{\circ} \mathrm{C} \mathrm{m}^{-1}$ \\
\hline
\end{tabular}

surface elevation matches the DEM of 2009 within a root-meansquare error of $7.1 \mathrm{~m}$ over all grid cells. No spatial trends in the elevation bias were detected.

The cumulative ice volume loss in the drainage basin of Findelengletscher agrees with the glacier volume change 1982-2007 determined based on the geodetic method (Farinotti et al., 2012), but is slightly more negative compared to the observed volume change 2005-2010 (Joerg et al., 2012, Fig. 3a). The altitudinal distribution of winter accumulation and annual mass balance is captured by the model (Fig. 3b), but ablation is overestimated systematically for 2005-2012. Monthly summer runoff volumes are reproduced with a model efficiency criterion after Nash and Sutcliffe (1970) of $R^{2}=0.89$, and the bias between measured and simulated runoff is within $4 \%$ for each month (Fig. 3c).
Observed and simulated daily runoff hydrographs at the gauging station agree well (Fig. 4). From 1982 to 2010, Nash and Sutcliffe (1970)-values for daily discharge range between 0.76 and 0.96 , with an average of 0.88 . This result is satisfying given that the model has not been specifically tuned to the discharge series but to the storage change components (accumulation, ice volume loss) that ensure the closure of the water balance (see e.g., Schaefli and Huss, 2011).

\subsection{Experiments}

In order to evaluate the integrated uncertainty in future glacier retreat and runoff, a set of ten experiments is defined. Each experiment addresses one component of model uncertainty. The description of the related process is individually modified in the model implementation. By comparing the result of each experiment to a reference simulation based on the model and the parameters described above, the effect of the considered model modification on calculated runoff for the period 2013-2100 can be assessed.

Key characteristics of all experiments are compiled in Table 3 and are described in more detail below. The experiments are separated into the driving climatological input given by the RCMs (Exp. I), and its treatment in the glacio-hydrological model (Exp. II-X). The runoff model uncertainties can be further divided into
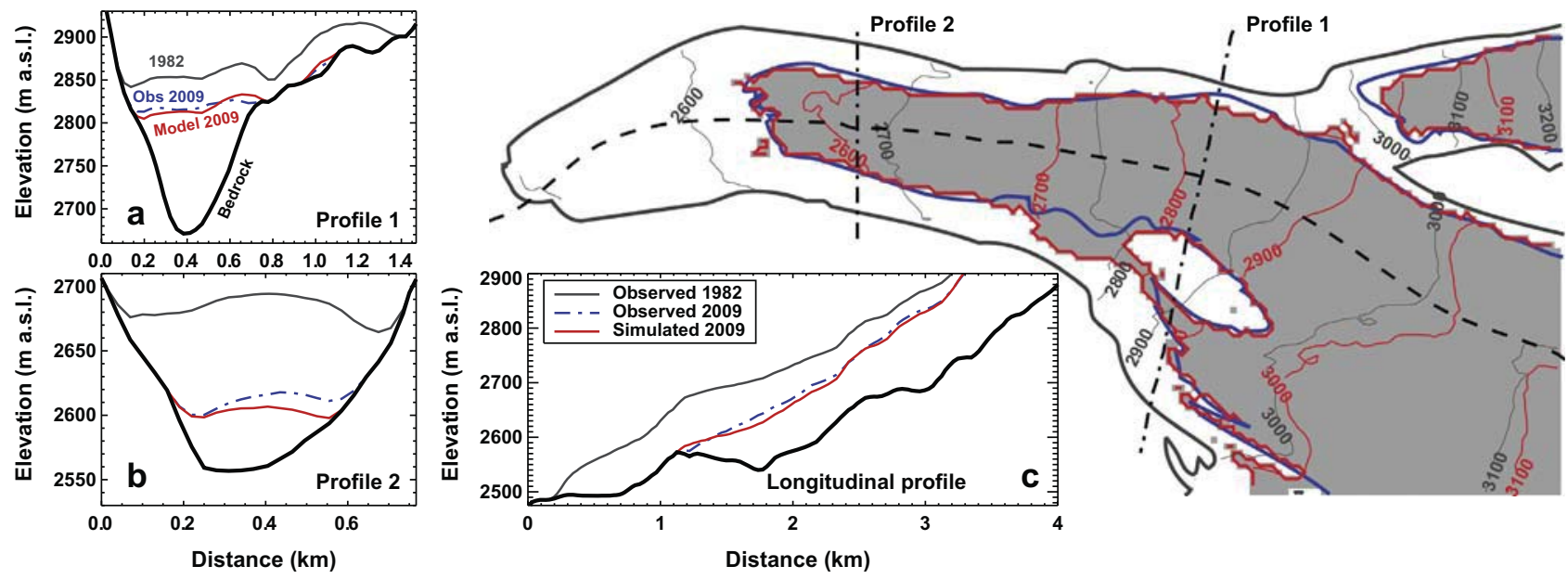

Fig. 2. Validation of calculated glacier retreat. Simulated (red) and observed (blue) glacier extent for the ablation area of Findelengletscher after running the model from 1982 to 2009. The insets show (a, b) cross-sections of the glacier tongue, and (c) a longitudinal profile. (For interpretation of the references to colour in this figure legend, the reader is referred to the web version of this article.)
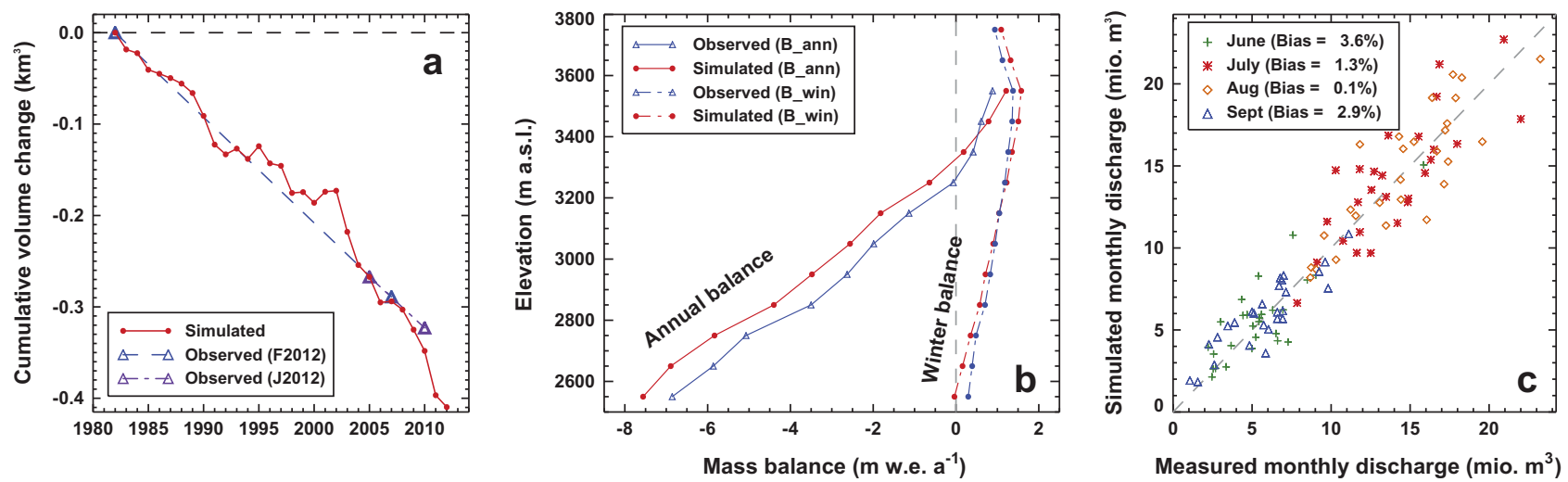

Fig. 3. (a) Calculated cumulative ice volume change of Findelengletscher for the period 1982-2012 in comparison to observations based on the geodetic method (F2012: Farinotti et al., 2012; J2012: Joerg et al., 2012). (b) Modeled and measured annual mass balance (average 2005-2012) and winter balance (average 2005, 2009-2012) for $100 \mathrm{~m}$ elevation bands. (c) Measured vs. simulated monthly runoff volume. The months June to September for 1983-2010 are symbol-coded, and the relative bias is given. 

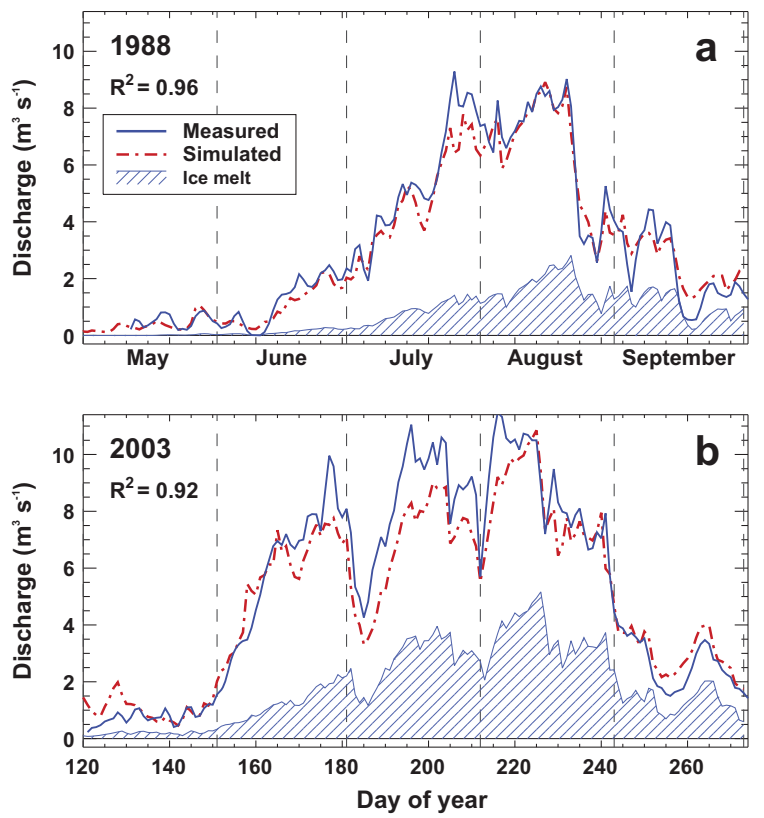

Fig. 4. Calculated and measured daily runoff from the catchment of Findelengletscher over the melting seasons of (a) 1988, and (b) 2003. The Nash and Sutcliffe (1970)-value $\left(R^{2}\right)$ is given. Hatched areas indicate runoff due to bare-ice melt.

the downscaling of the RCM data (Exp. II), the accuracy and availability of glaciological data for model calibration or initialization (Exp. III to V), and the description of glacio-hydrological processes (Exp. VI to X).

\subsubsection{Experiment I: Climate scenario}

The calibrated model is driven by changes in air temperature and precipitation given by nine RCMs based on evaluations within the CH2011 project (Bosshard et al., 2011, Table 1). Differences in runoff between the model runs are detached from the glaciohydrological model and depict the a priori uncertainty resulting from the use of different RCM outputs. The short-term meteorological variability as observed in the past is preserved for the modeling in the 21st century, and the RCM provides the long-term trends.

\subsubsection{Experiment II: Direct use of RCM data}

Climate models run at high temporal resolution and directly provide series of meteorological variables that include calculated internal changes in short-term variability and extreme values. By applying the 'delta change' approach, this potentially important information on the characteristics of future climate is not accounted for. However, the direct use of climate model results for driving impact models is not trivial and requires a careful data treatment (Kotlarski et al., 2010; Salzmann et al., 2012). The generation of future meteorological time series in hydrological studies is thus often based on the 'delta change' approach (e.g., Farinotti et al., 2012; Bavay et al., 2013). Experiment II investigates whether the procedure of downscaling RCM data has an impact on calculated glacier retreat and runoff.

For this experiment we generate a future daily meteorological time series different from the reference model. Daily air temperatures 1982-2012 directly given by each RCM for the grid point closest to Findelengletscher are first compared to the Zermatt weather station data, and a monthly bias between modeled and observed temperature is computed. Assuming the monthly bias to remain constant in time, continuous series for 1982-2100 are generated. Their daily temperature variability is given by the RCM and the series have the same long-term trends as for the 'delta change' approach. This experiment only addresses one part of the uncertainty introduced by the direct use of RCM data as climate model results on precipitation and radiation are not used. For these variables the series are identical to the reference model run. The ability of the RCMs to yield local short-term variations in precipitation and radiation are not judged as high enough. This is supported by the evaluations by Salzmann et al. (2012) who found that RCMs often fail to reproduce observed daily precipitation patterns in the Alpine region. In this experiment, the parameter $k_{1}$ (see Eq. (3)) of the reference model is re-calibrated over 1982-2012 using the bias-corrected daily RCM series as input.

\subsubsection{Experiment III: Calibration data}

In Experiment III, we exclude the primary calibration source of the glacio-hydrological model (volume change 1982-2007), and calibrate the model for a shorter period (2005-2010) to ice volume change observations. This allows assessing the impact of limited data availability and a short calibration period on calculated runoff. Only the parameter $k_{1}$ (Eq. (3)) was re-calibrated and no other changes were applied to the model geometry, and the parameters of the reference model.

\subsubsection{Experiment IV: Ice volume}

Measurements of ice thickness are scarce and glacier volume estimates are associated with considerable uncertainties. Based on different approaches, the uncertainty in glacier volume calculations without a priori knowledge on ice thickness has been estimated as about $\pm 30 \%$ (e.g., Gabbi et al., 2012; Huss and Farinotti, 2012; Linsbauer et al., 2012). To assess the impact of this uncertainty source, the observation-based ice thickness distribution of

Table 3

Experiments to assess different uncertainty components in future glacier runoff projections. See text for more detailed descriptions.

\begin{tabular}{|c|c|c|c|c|}
\hline Exp. & & Topic & Short description & Related studies \\
\hline I & & Climate scenario & Model driven with results from nine different RCMs ('delta change' approach) & Bosshard et al. (2011) \\
\hline II & & Direct use of RCM data & Model directly driven by downscaled daily RCM output & Salzmann et al. (2012) \\
\hline III & & Calibration data & Model calibration restricted to a short period (2005-2010) & Joerg et al. (2012) \\
\hline \multirow[t]{2}{*}{ IV } & a & Ice volume & Measured ice thickness reduced by $30 \%$ & Gabbi et al. (2012) \\
\hline & b & & Measured ice thickness increased by $30 \%$ & Gabbi et al. (2012) \\
\hline \multirow[t]{2}{*}{$\mathrm{V}$} & a & Snow accumulation & No spatial variability in snow accumulation distribution $(D(x, y)=1$, Eq. 2$)$ & Sold et al. (2013) \\
\hline & b & & Model purely calibrated on discharge; snow accumulation and melt data not considered & Verbunt et al. (2003) \\
\hline VI & & Glacier retreat & Glacier surface updated in 10 -year steps using the AAR-method & Paul et al. (2007) \\
\hline \multirow[t]{2}{*}{ VII } & a & Melt model & Calculation of snow and ice melt using a distributed degree-day model & Hock (1999) \\
\hline & $\mathrm{b}$ & & Calculation of snow and ice melt using an enhanced temperature-index model & Pellicciotti et al. (2005) \\
\hline \multirow[t]{2}{*}{ VIII } & a & Snow albedo param. & Snow albedo constant at $\alpha_{\text {snow }}=0.7$ & Machguth et al. (2006b) \\
\hline & b & & Brock-parameterization for snow albedo change & Brock et al. (2000) \\
\hline IX & & Ice surface albedo & Bare-ice albedo reduced to $\alpha_{\text {ice }}=0.1$ & Oerlemans et al. (2009) \\
\hline $\mathrm{x}$ & & Supraglacial debris & Prescribed debris-coverage dynamically thickening and expanding & Anderson $(2000)$ \\
\hline
\end{tabular}


Findelengletscher is scaled with a factor $f=0.7$, mimicking a $30 \%$ ice volume underestimate (Exp. IV-a), and $f=1.3$, corresponding to an ice volume overestimate (Exp. IV-b). The model is run with the reference settings.

\subsubsection{Experiment V: Snow accumulation}

Several studies show that the unambiguous calibration of hydrological models in glacierized basins requires the incorporation of data on glacier mass balance, as measured discharge alone does not carry sufficient information on the source of runoff, i.e. melt or precipitation (Konz and Seibert, 2010; Schaefli and Huss, 2011; Mayr et al., 2013). Experiment V addresses the impact of lacking information on winter snow accumulation, which is a common problem in many glacio-hydrological studies (e.g., Verbunt et al., 2003; Finger et al., 2012; Uhlmann et al., 2013a).

Sub-Experiment V-a assumes that the total amount of winter snow is equal to the reference simulation, but that the spatial distribution of accumulation is unknown. To this end, $D(x, y)$ (Eq. (2)) is set to 1 everywhere on the glacier, assuming that there is no spatial variability in snow accumulation. For sub-Experiment V-b, no information on winter snow accumulation at all is assumed to be available for model calibration. The model is calibrated to discharge data only, without validating against seasonal mass balance or glacier front variations. This re-calibrated parameter set yields significantly less snow ( $c_{\text {prec }}=2.0$, see Table 2 for comparison), and less melt $\left(k_{1}=10 \mathrm{~W} \mathrm{~m}^{-2}{ }^{\circ} \mathrm{C}^{-1}\right)$ which compensate for each other in terms of runoff.

\subsubsection{Experiment VI: Glacier retreat}

Some hydrological studies in glacierized basins calculate glacier retreat based on mass-conserving parameterizations (Huss et al., 2008; Weber et al., 2010; Ragettli et al., 2013), or physical ice flow modeling (Immerzeel et al., 2012). The glacier modules of most hydrological models, however, are static and do not allow a transient simulation of the ice melt contribution (e.g., Schaefli et al., 2005; Rössler et al., 2012; Bavay et al., 2013). In these studies, glacier area is updated in discrete time steps assuming the glacier to be in equilibrium with current climate conditions according to the so-called Accumulation Area Ratio (AAR)-method (Paul et al., 2007). Glacier surface elevation is kept constant.

In Experiment VI, glacier area $A$ is updated in 10-year time intervals based on the calculated area of the accumulation zone $A_{\text {acc }}$ and $A A R_{0}=60 \%$ (Paul et al., 2007) as

$A=A_{\mathrm{acc}} / A A R_{0}$.

All other model settings correspond to the reference simulation.

\subsubsection{Experiment VII: Melt model}

Experiment VII investigates differences in calculated runoff based on several widely used melt model formulations driven with the same input data. Experiment VII-a employs a distributed temperature-index model proposed by Hock (1999). The model is calibrated over the period 1982-2012 based on the same data as the reference model. Melt $M=M(x, y, t)$ is calculated using the empirical factors $f_{\mathrm{M}}=1.59 \mathrm{~mm}$ w.e. $\mathrm{d}^{-1}{ }^{\circ} \mathrm{C}^{-1}, \quad r_{\text {snow }}=0.0127$ and $r_{\text {ice }}=0.0254 \mathrm{~mm}$ w.e. $\mathrm{m}^{2} \mathrm{~W}^{-1} \mathrm{~d}^{-1}{ }^{\circ} \mathrm{C}^{-1}$, the potential solar radiation $I_{\mathrm{pot}}$, and air temperature $T$ as

$M=\left(f_{\mathrm{M}}+r_{\text {snow } / \text { ice }} \cdot I_{\text {pot }}\right) \cdot T \quad T>T_{\mathrm{M}}$

For $T$ below a threshold $T_{\mathrm{M}}=0{ }^{\circ} \mathrm{C}$ no melting occurs.

In addition, we apply an Enhanced Temperature-Index (ETI) model (Pellicciotti et al., 2005) which is based on the degree-day approach, but is closer to the energy balance formulation of the reference model (Eq. (3)). The parameters $f_{\mathrm{T}}=2.1 \mathrm{~mm}$ w.e. $\mathrm{d}^{-1}{ }^{\circ} \mathrm{C}^{-1}$ and $r_{\mathrm{sw}}=0.2256 \mathrm{~mm}$ w.e. $\mathrm{m}^{2} \mathrm{~W}^{-1} \mathrm{~d}^{-1}$ are fitted to the field data, and melt $M$ above $T_{M}=1{ }^{\circ} \mathrm{C}$ (Pellicciotti et al., 2005) is obtained as
$M=f_{\mathrm{T}} \cdot T+r_{\mathrm{sw}}(1-\alpha) \cdot G \quad T>T_{\mathrm{M}}$,

where the calculation of the global radiation $G$, and the albedo $\alpha$ correspond to the reference model (Eqs. (4) and (5)).

\subsubsection{Experiment VIII: Snow albedo}

To test the impact of the snow albedo parameterization on modeled future glacier retreat and runoff, $\alpha_{\text {snow }}$ is set to 0.7 as a constant in time and space for Experiment VIII-a (see e.g., Machguth et al., 2006b). For Experiment VIII-b, we use an alternative snow albedo parameterization after Brock et al. (2000). This approach evaluates $\alpha_{\text {snow }}$ as a function of the accumulated daily maximum temperatures $T_{\mathrm{m} \text {,acc }}$ since the last snowfall as

$\alpha_{\text {snow }}=\alpha_{\text {snow }, 0}-c_{\alpha} \log _{10} T_{\mathrm{m}, \mathrm{acc}}$,

with $\alpha_{\text {snow, } 0}$ the albedo of fresh snow, and $c_{\alpha}=0.106$ an empirical constant (Brock et al., 2000). For both supplementary approaches to calculate snow albedo, the parameter $k_{1}$ of the reference model is re-calibrated.

\subsubsection{Experiment IX: Ice albedo}

With ongoing glacier wastage, the darkening of bare-ice surfaces due to accumulation of mineral dust, black carbon and the growth of algae is observed (e.g., Oerlemans et al., 2009). The associated decrease in ice surface albedo represents a significant additional forcing term. For the terminus of Vadret da Morteratsch, Switzerland, Oerlemans et al. (2009) found a local albedo change from 0.32 to 0.15 over the first decade of the 21st century. Experiment IX addresses this potential albedo change by drastically decreasing $\alpha_{\text {ice }}$ from 0.25 to 0.1 for the entire future modeling period.

\subsubsection{Experiment $X$ : Debris coverage}

Supraglacial debris is observed on a considerable number of alpine glaciers and is the dominant surface type in the ablation area of some regions (e.g., Kayastha et al., 2000; Scherler et al., 2011). As soon as debris thickness is larger than a few centimeters, ice melt is reduced substantially (e.g., Nicholson and Benn, 2006; Hagg et al., 2008). With glacier retreat both a thickening of the supraglacial debris layer and an expansion of the debris-covered area is expected (Anderson, 2000).

Although Findelengletscher only has a minor debris-coverage, we test the influence of supraglacial debris on future glacier retreat and runoff by artificially prescribing debris-covered ice below an elevation of $3000 \mathrm{~m}$ a.s.l., i.e. about $50 \%$ of the ablation area. In Experiment X, calculated melt for debris-covered ice is multiplied by a reduction factor $f_{\text {debris }}=0.5$ (Huss et al., 2007) corresponding to a debris thickness of $0.1 \mathrm{~m}$ (Reid and Brock, 2010) that is typical for Alpine glaciers. In the model run until 2100 , debris cover is treated as a dynamic layer that progressively thickens to a maximum of about $0.3 \mathrm{~m}$ by 2100 . This is described by a continuous decrease in $f_{\text {debris }}$ of $0.002 \mathrm{yr}^{-1}$. The outward propagation of debris coverage in space and time is simulated according to an approach proposed by Jouvet et al. (2011). Feedback effects due to ice cliffs and ponds that increase melt in the debris-covered area (Benn et al., 2012) are not included; our experiment thus represents an upper bound for the debris-cover effect.

\section{Results}

We perform model runs for the changes in climate forcing given by each of the nine RCMs (Exp. I, Table 1). For Experiments II-X (Table 3) the model is run with changed input data, different sets of calibrated parameters, or modifications in the model structure for the median RCM. The results are compared to the reference simulation. The reference model is based on the ECHAM5 driven 
REMO regional climate model, the model set-up is described in Section 3.1, and the values of the most important parameters are given in Table 2.

Based on the reference model we expect a significant mass loss of Findelengletscher over the 21st century (Fig. 5). A total glacier terminus retreat of $1.5 \mathrm{~km}$ until 2030 is calculated. Between 2010 and 2060, ice volume is reduced more than 50\% (Fig. 5), resulting in a glacier area of less than $2 \mathrm{~km}^{2}$ by the end of the 21st century (Fig. 6a).

The reference model indicates an increase in annual runoff until about 2055 (Fig. 6b) due to release of water from long-term glacial storage. Afterwards, the smaller glacier area can no longer maintain increasing flow. A slight increase in evapotranspiration is calculated by GERM. Together with the reduced excess runoff from glacier wastage, this causes a decrease in annual runoff until 2100 (Fig. 6b). Strong shifts in the hydrological regime are found resulting in a significant decrease in summer runoff, and a peak melt discharge occurring about 1.5 months earlier in the season (Fig. 6c).

Forcing the glacio-hydrological model with different changes in air temperature and precipitation as prescribed by the nine RCMs leads to a considerable spread in the results (Fig. 6). Calculated glacier area loss by 2100 varies between $-68 \%$ and $-98 \%$ relative to 2007. The peak in annual runoff volume is reached between 2040 and about 2065 (Fig. 6b). Differences in modeled glacier area and runoff relative to the observation period mean are shown in Fig. 7. Whereas the uncertainties in calculated annual runoff volume due to the choice of the RCM remain within $\pm 20 \%$ of the reference model throughout the modeling period, August runoff by 2100 deviates from the reference by $-62 \%(+51 \%)$ for the RCM providing maximum (minimum) changes in air temperature. This confirms that considering multi-model GCM-RCM-chains in projections of future runoff is indispensable to render a plausible spread in the results due to the intrinsic climate model uncertainty.

According to Experiment II, the approach for generating a daily temperature time series from the RCM output for driving the
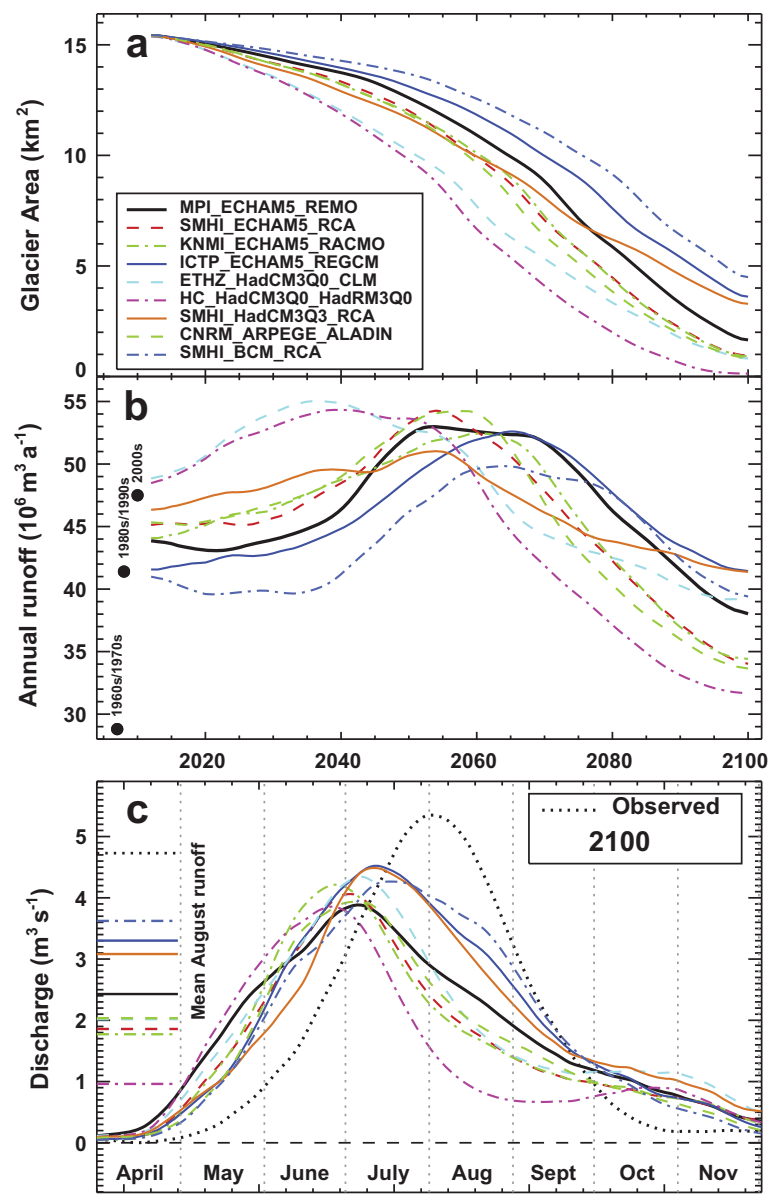

Fig. 6. Calculated changes in (a) glacier area, (b) annual runoff, and (c) runoff hydrographs (by 2100) based on climatic conditions prescribed by nine RCMs (Exp. I). The reference model is shown with the solid black line. Decadal means of measured annual runoff are indicated with dots in (b), and the observed runoff regime (1962-2010) is shown in (c).
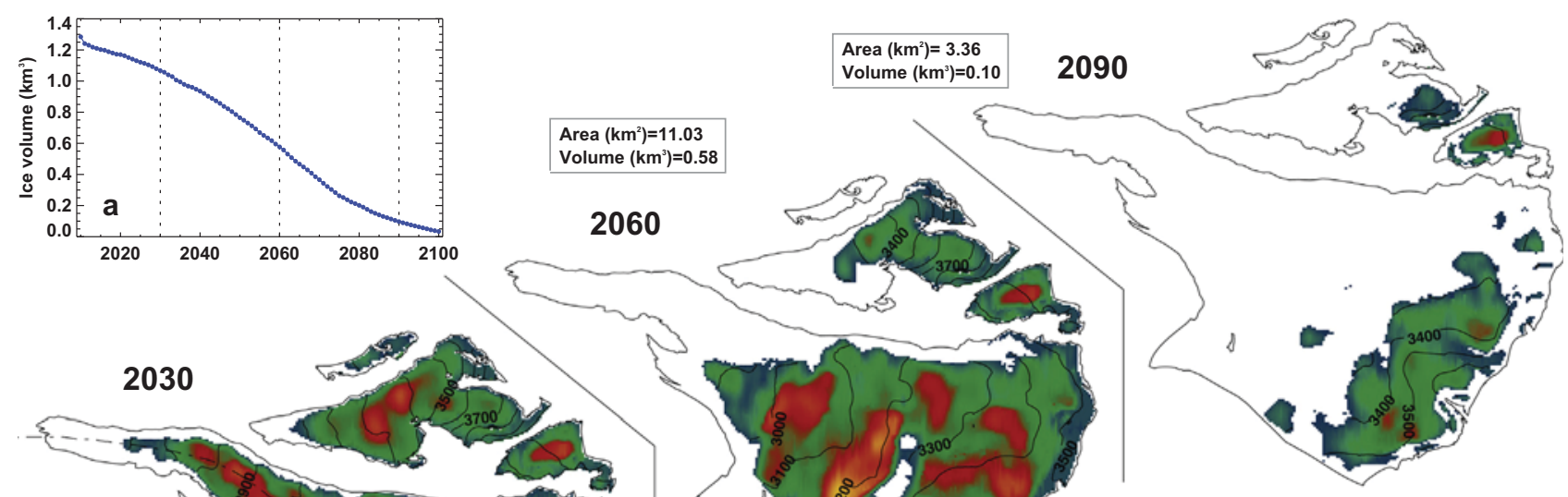

2030
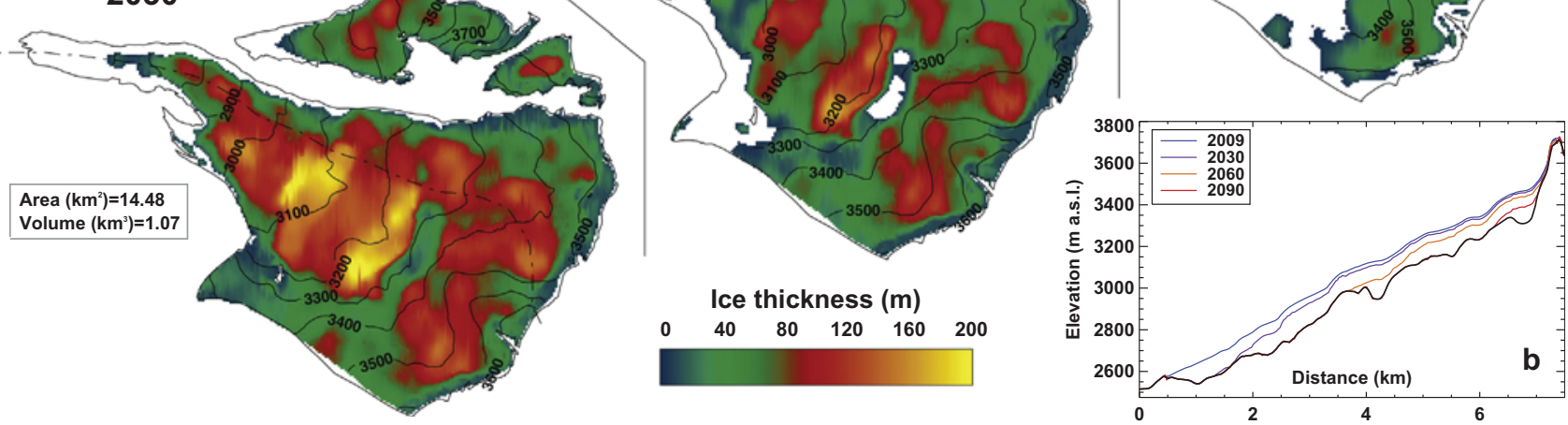

Fig. 5. Modeled glacier retreat and ice thickness in 2030, 2060, and 2090 according to the median RCM and the reference model. The glacier outline of 2010 is depicted. Insets show (a) the evolution of glacier ice volume, and (b) ice surface topography in a longitudinal profile (dashed line in first panel). 

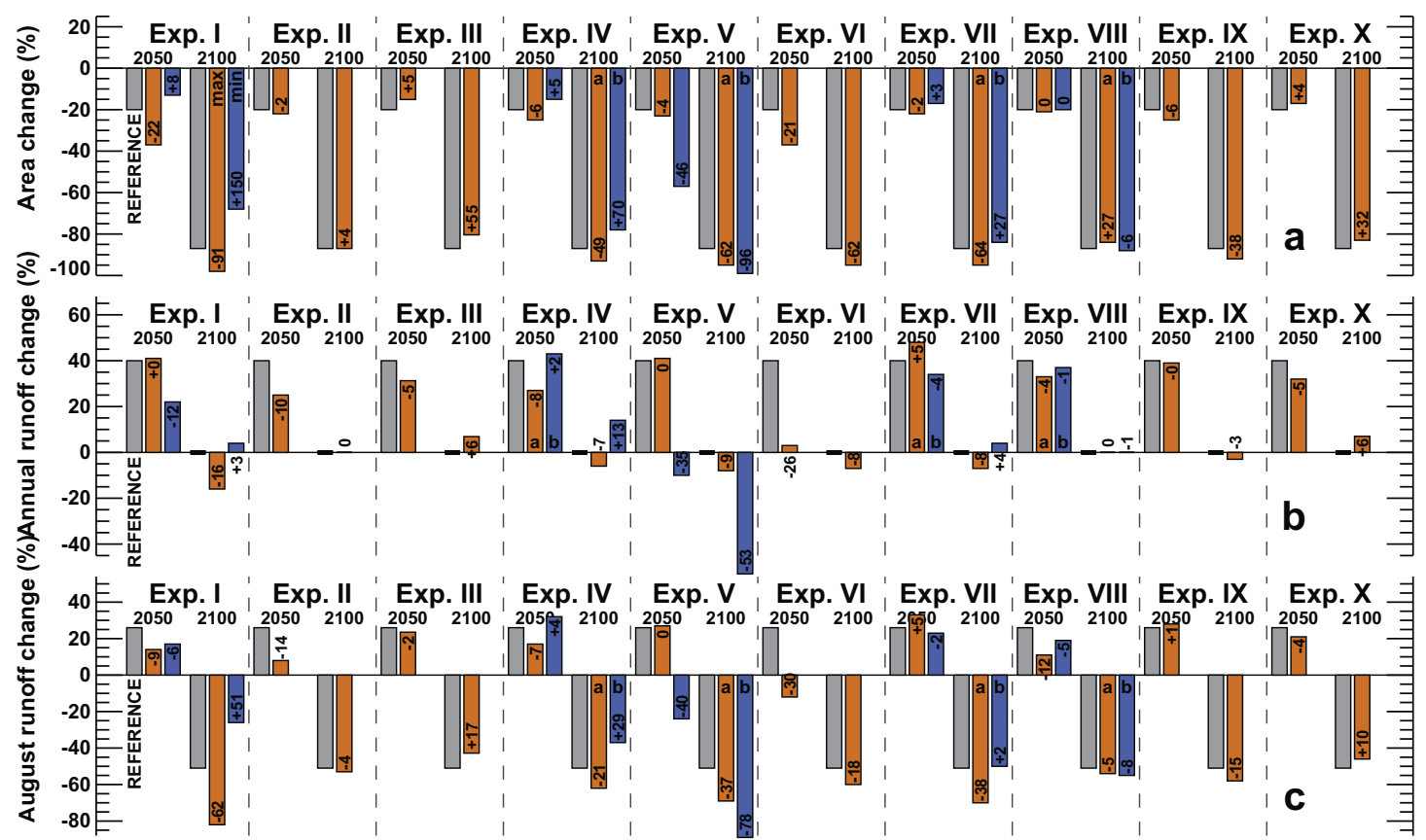

Fig. 7. Changes in (a) calculated glacier area relative to 2007, (b) annual runoff and (c) August runoff relative to observations (mean $1962-2010$ ) by 2050 and 2100. Bars show results for the reference model and each experiment (cf. Table 3). Numbers in the bars state the difference of calculated area/runoff relative to the reference model result by 2050 and 2010, respectively, in percent. For Experiment I, only model runs with maximum/minimum changes are given. Orange bars refer to the results of every experiment, and blue bars to sub-Experiment b, if available. (For interpretation of the references to colour in this figure legend, the reader is referred to the web version of this article.)

hydrological model has a limited impact on the results (Fig. 8a). Glacier area and runoff change calculated with the bias-corrected daily RCM time series are within $\pm 10 \%$ of the results based on the 'delta change' approach and no systematic differences are evident except for a spin-up effect in the first decade of the modeling. Considering monthly to seasonal changes in the mean of meteorological variables ('delta change' approach) and daily variability as observed in the past seems to be sufficient for capturing the governing processes. This conclusion might however not be valid for applications other than glaciers where the short-term variability or extreme events (also in terms of precipitation) are more important.

The calibration data used for constraining the hydrological model have a considerable effect on calculated glacier change and runoff (Fig. 8b). In Experiment III, the rate of modeled glacier mass loss is reduced, and the expected August runoff in 2100 is higher by $17 \%$ relative to the reference model (Fig. 7 ). This indicates that runoff projections over the 21st century are sensitive to the availability of calibration data, and the time period covered by these data.

For an ice thickness underestimate (Exp. IV-a), glacier area loss is accelerated leading to annual runoff volumes $14 \%$ below the reference model by 2075 (Fig. 9). In contrast, glacier response to the same changes in climate is delayed in the case of an ice thickness overestimate (Exp. IV-b). Runoff volumes remain higher than today throughout almost the entire 21st century, and no water shortage - even during the summer months - is expected (Fig. 9). Experiment IV emphasizes the importance of knowledge about the ice volume presently stored in glacierized basins to correctly model future runoff, and consequent impacts on the management of water resources.

Experiment $\mathrm{V}$ demonstrates that information on winter snow accumulation is highly important for correctly simulating future changes in runoff for several reasons. If data on the quantity of accumulation are available but the spatial snow distribution is not accounted for (Exp. V-a), Findelengletscher retreats considerably faster and shifts in the hydrological regime are accelerated (Fig. 10). For example, a decrease in August discharge by $22 \%$ is expected until 2075 , whereas the reference model predicts almost stable runoff $(-3 \%)$. In this experiment the model ignores spatial accumulation patterns on Findelengletscher that have been detected based on measurements.

A complete lack of snow accumulation data (Exp. V-b), and a calibration of the hydrological model on measured discharge alone has drastic consequences on projected runoff (Fig. 10). A complete disintegration of the glacier is found for 2080. No transient discharge increase (as for all other experiments) is simulated, and a long-term reduction in annual runoff by more than $50 \%$ is evident (Fig. 10b). Simulated runoff in August is smaller by $80 \%$ in this experiment at the end of the 21st century compared to the reference model (Fig. 7). The mistakes in setting the accumulation and the melt parameters for this model experiment are obvious; a compensation of too little precipitation by additional ice melt remained undetected in the calibration period as no data on the components of runoff (winter accumulation, glacier melt) were considered. Experiment V shows that including data on storage change components for constraining long-term hydrological projections is crucial to their accuracy.

The AAR-method to update ice surface extent (Exp. VI) is not mass conserving, i.e. ice volume can be lost without contributing to discharge, and assumes the glacier always to be in equilibrium with climate. This leads to underestimated glacier areas throughout the 21st century and annual runoff values systematically below (up to 30\%) the reference model (Fig. 7 and Fig. 8c). According to this experiment, the general evolution of future runoff characteristics in glacierized basins is strongly affected by the glacier retreat calculation, which is still rudimentary in many glacio-hydrological models.

The degree-day model (Hock, 1999) leads to slightly faster glacier mass loss compared to the reference (Exp. VII-a). An earlier peak in annual runoff is found (Fig. 8d). This indicates a higher sensitivity of this model to air temperature change. The ETI-model 


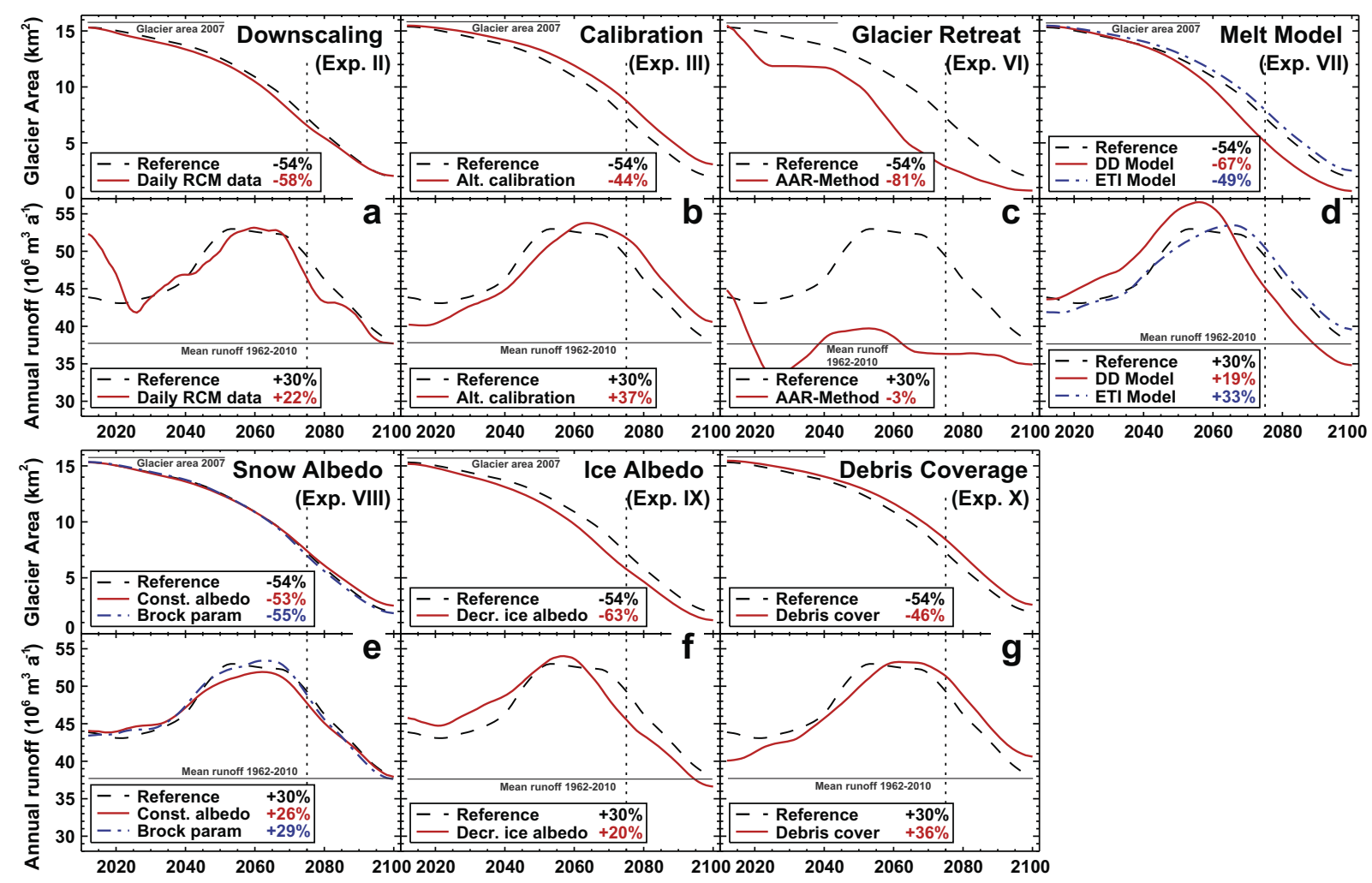

Fig. 8. Transient changes in glacier area and annual runoff calculated for the reference model and (a) an alternative downscaling of RCM data (Exp. II), (b) a shorter calibration period (Exp. III), (c) a different model for glacier retreat (Exp. VI), (d) two other approaches to compute snow and ice melt (Exp. VII), (e) alternative parameterizations for snow albedo (Exp. VIII), (f) reduced bare-ice albedo (Exp. IX), and (g) a debris-covered glacier tongue. Relative changes compared to initial glacier area (2007), and mean observed runoff in 1962-2010 are given in \% for the year 2075 .
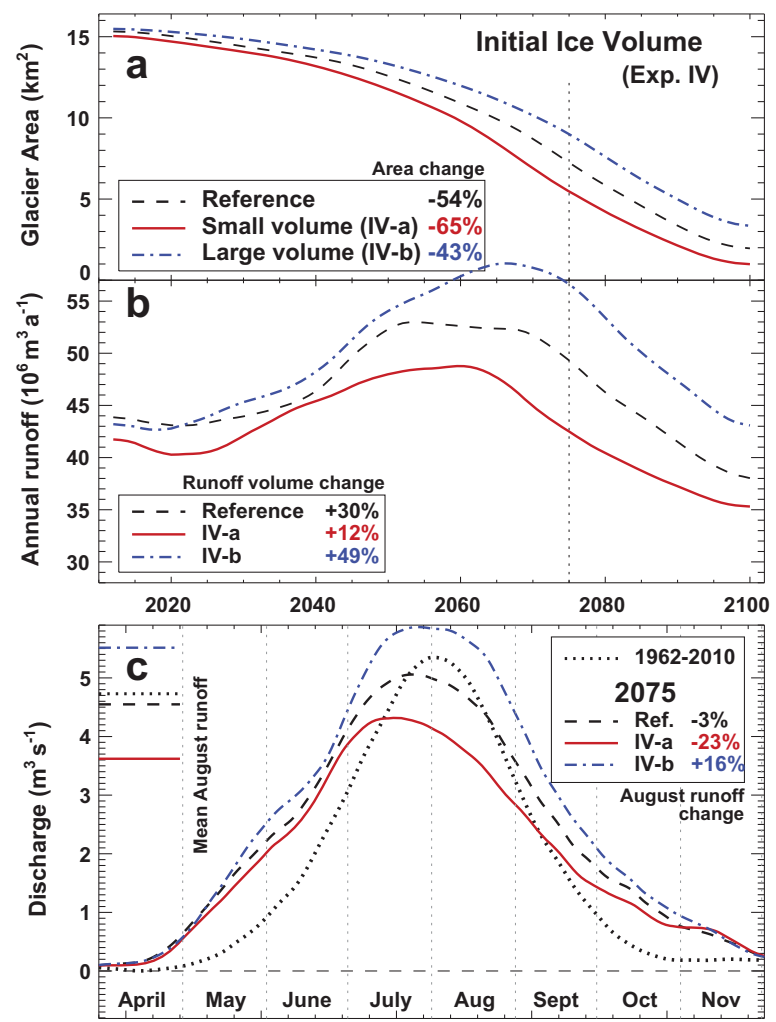

Fig. 9. Changes in (a) glacier area, (b) annual runoff, and (c) runoff hydrographs based on different assumptions of initial ice volume (Exp. IV). Relative changes compared to glacier area in 2007, and mean runoff $1962-2010$ are given in \% for the year 2075 .

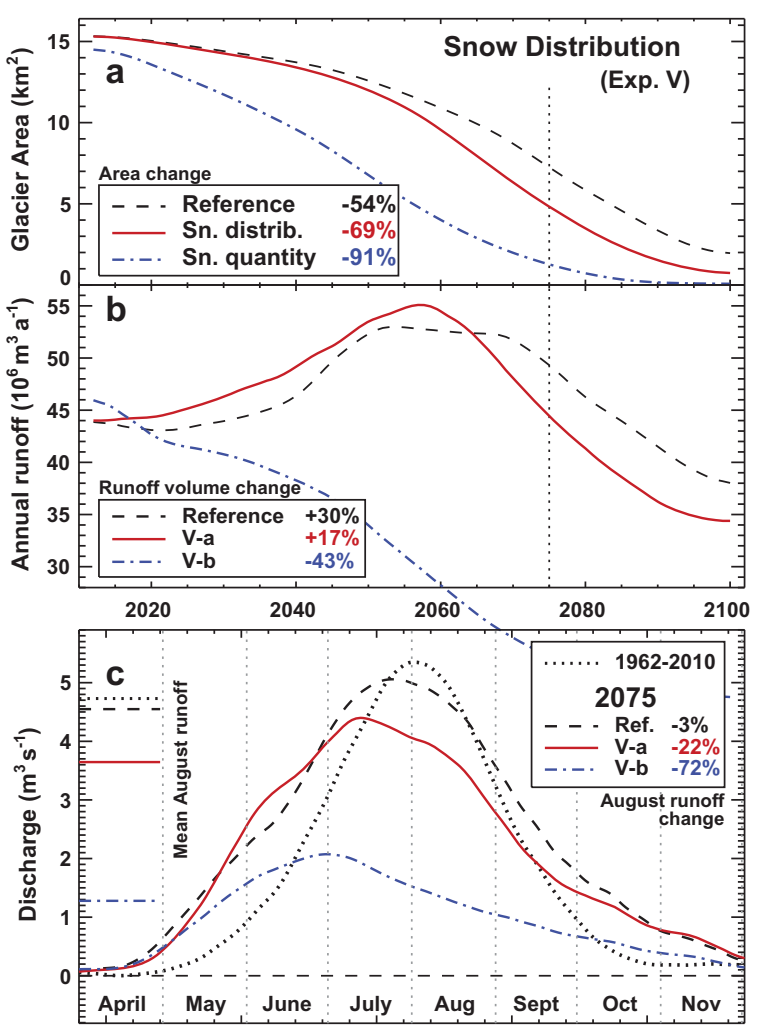

Fig. 10. Changes in (a) glacier area, (b) annual runoff, and (c) runoff hydrographs based on a different availability of winter snow accumulation data (Exp. V). Relative changes compared to initial area (2007), and mean runoff 1962-2010 are given in \% for the year 2075 . 
(Pellicciotti et al., 2005) results in moderately slower glacier response to prescribed climatic conditions. The uncertainties in terms of August runoff due to the choice of the melt model are in the range of $\pm 5-10 \%$ (Fig. 7). This issue is thus less important compared to Experiments III-VI.

The parameterization to calculate snow albedo (Exp. VIII) has a relatively small effect on calculated future runoff (Fig. 8e). Although the differences in snow albedo used in the modeling are considerable and strongly alter the energy balance, errors seem to cancel each other out, and the uncertainties in projected annual runoff remain within $\pm 3 \%$ (Fig. 7). Assuming temporally constant snow albedo, a decelerated glacier area change is found, which is attributed to a likely snow albedo decrease over the next decades due to reduced frequencies of fresh snow falls and warmer winter temperatures.

Drastically decreasing albedo in the bare ice region (Exp. IX) leads to an acceleration of glacier area loss and an earlier shift in the hydrological regime (Fig. 8f). This crucial parameter in the energy balance of ice surfaces does however only trigger relatively moderate differences in calculated runoff (around $\pm 7 \%$ ) compared to the reference model (Fig. 7).

The extensive supraglacial debris coverage prescribed in Experiment $\mathrm{X}$ delays the calculated area loss of Findelengletscher (Fig. 8g). Peak annual runoff occurs 10 years later, and discharge in August is $10 \%$ higher by 2100 compared to the reference model (Fig. 7). Debris-covered ice is only found in the ablation area, and its modeled propagation in space is slower than the rise in equilibrium lines over the 21st century. Even the about threefold thickening assumed does not completely stop the melting process (e.g., Nicholson and Benn, 2006). The importance of accounting for the feedback of supraglacial debris in runoff projections strongly depends on the characteristics of the investigated glacier. The effect lies in the range of the processes investigated in Experiments VII-IX, and is thus relatively small given that our assumptions rather represent an upper bound for the potential impact.

\section{Discussion}

Uncertainties in runoff projections from high-mountain drainage basins need to be addressed in an integrative way in order to provide reasonable error bars for the management of water resources. Basically, uncertainties due to (1) the climate models and (2) the approach to translate the changes in climate into a runoff response, i.e. the glacio-hydrological impact model, can be discerned. Different trends in air temperature, precipitation and other variables provided by the climate models represent the a priori uncertainty. Additional uncertainties due to simplifications and imperfect input data are inherent to all models used in environmental sciences. These effects are difficult to assess as in most cases no alternative (or 'better') model and/or more accurate input data are available. Therefore, the integrative uncertainty of the glacio-hydrological model is relatively poorly known.

For calculating a combined overall uncertainty in modeled future runoff, Experiments II to X were repeated by forcing the model with two extreme RCMs (Table 1) defining a lower and an upper bound of expected climate change. Thus, runoff time series including both the maximal effect of RCM uncertainty and each individual impact model uncertainty were obtained. Note that we did not superimpose Experiments II to $\mathrm{X}$ as we consider them to be independent of each other. This overall uncertainty assessment merges the results of Experiment I (RCM uncertainty) with each component of the hydrological model uncertainty (Exp. II to X) and allows (i) judging the importance of uncertainties in the impact model relative to the range given by the nine RCMs, and (ii) provides a combined multi-experiment uncertainty in future runoff.
Fig. 11 shows the overall uncertainties in calculated annual and monthly runoff separated into the contributions of the RCM and the glacio-hydrological impact model. Over most of the 21st century, the spread in the climate model results accounts for $20-50 \%$ of the total uncertainty in annual runoff. The remaining uncertainty is explained by the description of individual processes in the hydrological model (Fig. 11a). The intermediate drop in the importance of the RCM uncertainty around 2050 is site-specific and can be attributed to the timing of runoff changes related to the transition from a glacierized to a non-glacierized catchment (see e.g., Baraer et al., 2012).

For monthly discharge around 2050, the hydrological model accounts for around $90 \%$ of the total uncertainty range in July and August (Fig. 11b). This indicates that for providing well founded projections of transient runoff changes over the next decades, a careful quality assessment of the glacio-hydrological model is indispensable. By 2100, the overall monthly runoff uncertainty ranges are similar as in 2050 but they are dominated to a stronger degree by the RCMs (Fig. 11b). After an almost complete loss of the glacierized area, some feedback effects - presently still an important source of model uncertainty - are less important.

Although results of all experiments show some consistent patterns (see e.g., Fig. 6), the uncertainties are remarkable. The RCM forcing and the uncertainties in the glacio-hydrological model
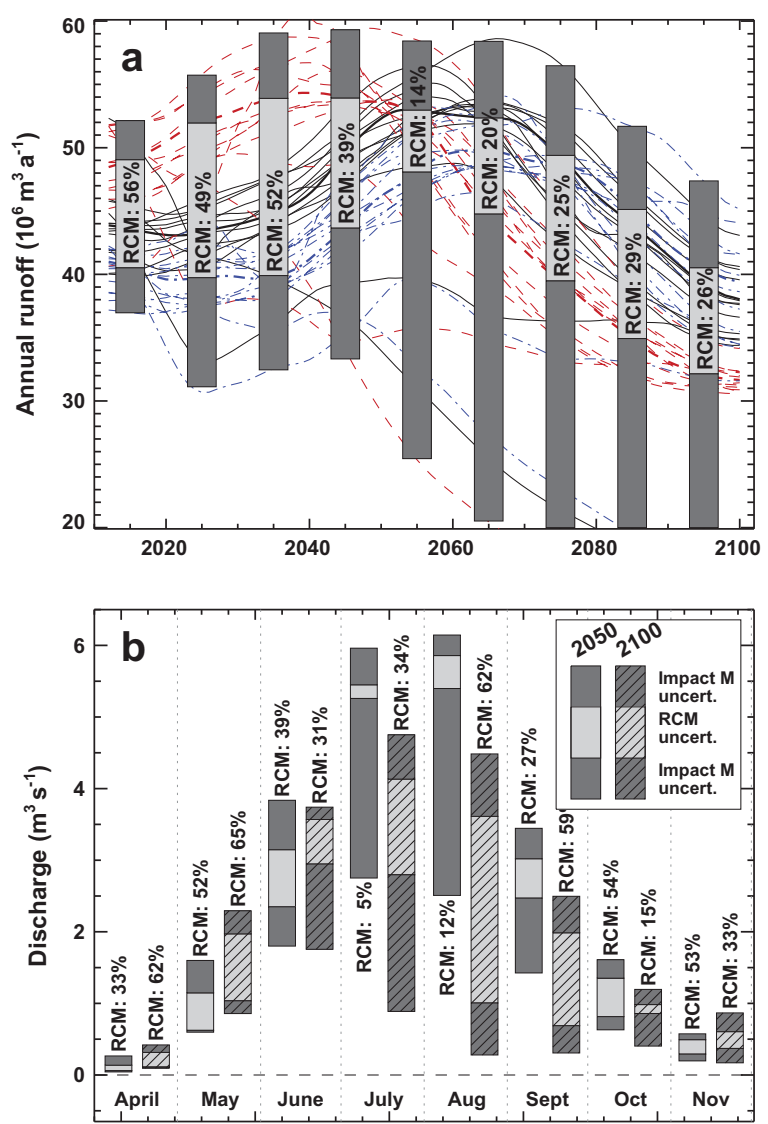

Fig. 11. Combined multi-experiment uncertainties in calculated (a) annual runoff and (b) mean monthly runoff by 2050 and 2100 (hatched). Light-shaded bars show runoff uncertainties due to the spread in RCM results ('RCM uncert.'), and darkshaded bars show the additional uncertainty due to superimposing individual uncertainties of the impact model (Exp. II to X) on extreme RCMs ('Impact M uncert.'). The percentage of the overall uncertainty explained by the RCM uncertainty is stated. Thin lines in (a) show model results for all experiments based on the median RCM (black) and the two extreme RCMs (red, blue). (For interpretation of the references to colour in this figure legend, the reader is referred to the web version of this article.) 
Table 4

Overall uncertainty range of the change in annual runoff $Q_{\text {annual }}$, and monthly runoff. All numbers are relative to the observed mean 1962-2010. The ranges refer to the combined uncertainty due to the spread in RCM results and the glacio-hydrological model (see also Fig. 11).

\begin{tabular}{llll}
\hline Year & $Q_{\text {annual }}(\%)$ & $Q_{\text {July }}(\%)$ & $Q_{\text {August }}(\%)$ \\
\hline 2025 & -18 to +48 & -15 to +40 & -23 to +35 \\
2050 & -22 to +56 & -38 to +34 & -47 to +30 \\
2075 & -53 to +50 & -70 to +27 & -89 to +22 \\
2100 & -57 to +25 & -80 to +7 & -94 to -5 \\
\hline
\end{tabular}

often dictate the sign of the runoff change (Table 4). Annual runoff by 2100 , for example, varies between $-57 \%$ and $+25 \%$ relative to 1962-2010. The runoff change calculated for August 2075 ranges from $-89 \%$ to $+22 \%$ among the experiments (Table 4 ). The same model driven with the output from different RCMs and realistic uncertainties in the input data and the description of relevant processes can thus predict conditions between severe water shortage and a considerable runoff surplus for the same time horizon. Note that for calculating these ranges, individual uncertainties in the glacio-hydrological model have not been superimposed. We thus provide a lower bound of the estimated uncertainty. These evaluations clearly highlight the importance of better investigating and communicating the high uncertainties in runoff projections.

The various model experiments allow quantitatively assessing the impact of individually considered uncertainty factors. We are aware, however, that the set-up of the experiments, i.e. the definition of input data uncertainty, is in some cases arbitrary and is specific to the investigated drainage basin. Our uncertainty estimates are still relatively conservative; individual components of the overall uncertainty might even be less constrained for catchments with poorer data availability. Furthermore, it was not possible to take into account all processes that potentially have systematic effects on the model results. Additional uncertainties might arise from subglacial ice melting, the interaction with proglacial lakes, increased long-wave radiation forcing from deglaciated mountain flanks and rock outcrops, or daily climate model outputs that were not specifically analyzed (precipitation, radiation). Thus, although its configuration is assumed to be optimal throughout the paper, the reference model only represents one possible evolution of glacier runoff over the 21st century.

The results presented here refer to one specific catchment in the Swiss Alps and the relative relevance of the individual components of uncertainty might vary for different climatological settings. The uncertainties calculated for the Findelengletscher catchment are thus not quantitatively transferable to other study sites. However, we presume that the ranking of the investigated processes regarding their potential uncertainty in runoff projection remains valid for a wide range of glacierized drainage basins.

\section{Conclusion}

Ten model experiments were performed to address various uncertainties in the modeling of future runoff response of glacierized drainage basins. Uncertainties in calculated discharge over the 21 st century are considerable and hamper the reliability of projections. Accounting for the spread in climate model results and typical uncertainties related to input data quality and model structure, we find that calculated changes in August runoff from the catchment of Findelengletscher, Switzerland, can range between $-94 \%$ and $-5 \%$ by 2100 compared to observations over the last decades. Also the overall uncertainties in glacier area ( $-100 \%$ to $-63 \%)$, and annual runoff $(-57 \%$ to $+25 \%)$ are noteworthy. These high uncertainty ranges in 21st century runoff projections from glacierized drainage basins indicate that model results need to be interpreted with care. Field measurements, in-depth process studies and new model approaches are required in order to reduce the uncertainties. Despite the major differences in simulated future runoff time series, some consistent patterns emerge from all experiments. A major glacier retreat is found and an initial increase in total catchment discharge is expected. Peak water is reached between 2035 and 2075 depending on the selected climate model and the settings of the runoff model.

Our model experiments show which uncertainties are most relevant for projecting future runoff in high-mountain catchments. The spread in the results of individual RCMs (Exp. I) determines one of the most important uncertainties in calculated future glacier retreat and discharge. It can only be taken into account by performing ensemble simulations instead of runs with only one climate model. Knowledge about the initial glacier ice volume (Fig. 9), and the quantity of winter snow accumulation and its spatial distribution (Fig. 10) is crucial for correctly capturing the future runoff response within a glacio-hydrological model. A lack of data on these variables can lead to considerable errors in predicted future runoff change. The approach to calculate glacier retreat is important as well (Fig. 8c); simplified models assuming immediate glacier response to changed climate conditions are likely to yield a strong underestimation of discharge. Our experiments indicate that the downscaling procedure of RCM data, the calibration data quality, the snow and ice melt model, the description of surface albedo and debris coverage have a secondary importance for shaping modeled future glacier runoff regimes. However, these factors still require additional research and a careful treatment in the glaciohydrological models.

\section{Acknowledgments}

This study was supported by the Swiss energy utility Axpo. VAW-ETHZ is acknowledged for photogrammetrical DEMs. Meteorological data used for the modeling were provided by MeteoSwiss, and discharge records were made available by Grande Dixence SA. We are grateful to everybody contributing to the field measurements on Findelengletscher over the last decade. R. Hock and M. Hoelzle provided comments on an earlier version of the manuscript. Reviews by W. Hagg and two anonymous reviewers were helpful to finalize the paper.

\section{References}

Anderson, R.S., 2000. A model of ablation-dominated medial moraines and the generation of debris-mantled glacier snouts. Journal of Glaciology 46, 459-469.

Baraer, M., Mark, B., McKenzie, J., Condom, T., Bury, J., Huh, K.I., Portocarrero, C. Gomez, J., Rathay, S., 2012. Glacier recession and water resources in Peru's Cordillera Blanca. Journal of Glaciology 58, 134-150. http://dx.doi.org/10.3189/ 2012JoG11J186.

Barnett, T.P., Adam, J.C., Lettenmaier, D.P., 2005. Potential impacts of a warming climate on water availability in snow-dominated regions. Nature 438,303-309.

Bauder, A., Funk, M., Huss, M., 2007. Ice volume changes of selected glaciers in the Swiss Alps since the end of the 19th century. Annals of Glaciology 46, 145-149.

Bavay, M., Grünewald, T., Lehning, M., 2013. Response of snow cover and runoff to climate change in high Alpine catchments of Eastern Switzerland. Advances in Water Resources 55, 4-16.

Beniston, M., 2003. Climatic change in mountain regions: a review of possible impacts. Climatic Change 59, 5-31.

Benn, D.I., Bolch, T., Hands, K., Gulley, J., Luckman, A., Nicholson, L.I., Quincey, D. Thompson, S., Toumi, R., Wiseman, S., 2012. Response of debris-covered glaciers in the Mount Everest region to recent warming, and implications for outburst flood hazards. Earth Science Reviews 114, 156-174.

Bosshard, T., Kotlarski, S., Ewen, T., Schär, C., 2011. Spectral representation of the annual cycle in the climate change signal. Hydrology and Earth System Sciences 15, 2777-2788. http://dx.doi.org/10.5194/hess-15-2777-2011.

Braun, L., Weber, M., Schulz, M., 2000. Consequences of climate change for runoff from Alpine regions. Annals of Glaciology 31, 19-25.

Brock, B.W., Willis, I.C., Sharp, M.J., 2000. Measurement and parameterization of albedo variations at Haut Glacier d'Arolla, Switzerland. Journal of Glaciology 46 675-688. 
Christensen, J.H., Christensen, O.B., 2007. A summary of the PRUDENCE model projections of changes in European climate by the end of this century. Climatic Change 81, 7-30.

Cuffey, K.M., Paterson, W.S.B., 2010. The Physics of Glaciers, forth ed. Butterworth, Heinemann, Oxford, p. 704

Farinotti, D., Huss, M., Bauder, A., Funk, M., 2009. An estimate of the glacier ice volume in the Swiss Alps. Global Planet. Change 68, 225-231. http:// dx.doi.org/10.1016/j.gloplacha.2009.05.004.

Farinotti, D., Magnusson, J., Huss, M., Bauder, A., 2010. Snow accumulation distribution inferred from time-lapse photography and simple modelling. Hydrol. Process. 24, 2087-2097. http://dx.doi.org/10.1002/hyp.7629.

Farinotti, D., Usselmann, S., Huss, M., Bauder, A., Funk, M., 2012. Runoff evolution in the Swiss Alps: projections for selected high-alpine catchments based on ENSEMBLES scenarios. Hydrol. Process. 26, 1909-1924. http://dx.doi.org/ 10.1002/hyp.8276.

Finger, D., Heinrich, G., Gobiet, A., Bauder, A., 2012. Projections of future water resources and their uncertainty in a glacierized catchment in the Swiss Alps and the subsequent effects on hydropower production during the 21st century. Water Resour. Res. 48, W02521. http://dx.doi.org/10.1029/2011WR010733.

Gabbi, J., Farinotti, D., Bauder, A., Maurer, H., 2012. Ice volume distribution and implications on runoff projections in a glacierized catchment. Hydrol. Earth Syst. Sci. 16, 4543-4556.

Hagg, W., Hoelzle, M., Wagner, S., Mayr, E., Klose, Z., 2013. Glacier and runoff changes in the Rukhk catchment, upper Amu-Darya basin until 2050. Global Planet. Change 110(A), 62-73.

Hagg, W., Mayer, C., Lambrecht, A., Helm, A., 2008. Sub-debris melt rates on southern Inylchek Glacier, central Tian Shan. Geografiska Annaler: Ser. A, Phys. Geogr. 90, 55-63.

Hay, L.E., Wilby, R.L., Leavesley, G.H., 2000. A comparison of delta change and cownscaled GCM scenarios for three mountainous basins in the United States. J. Am. Water Resour. Assoc. 36, 387-397.

Hock, R., 1999. A distributed temperature-index ice- and snowmelt model including potential direct solar radiation. J. Glaciol. 45, 101-111.

Hock, R., 2005. Glacier melt: a review of processes and their modelling. Progr. Phys. Geogr. 29, 362-391.

Huss, M., 2011. Present and future contribution of glacier storage change to runoff from macroscale drainage basins in Europe. Water Resour. Res. 47, W07511. http://dx.doi.org/10.1029/2007WR010299.

Huss, M., Farinotti, D., 2012. Distributed ice thickness and volume of all glaciers around the globe. J. Geophys. Res. 117, F04010. http://dx.doi.org/10.1029/ 2012JF002523.

Huss, M., Farinotti, D., Bauder, A., Funk, M., 2008. Modelling runoff from highly glacierized alpine drainage basins in a changing climate. Hydrol. Process. 22, 3888-3902. http://dx.doi.org/10.1002/hyp.7055.

Huss, M., Hock, R., Bauder, A., Funk, M., 2010a. 100-year mass changes in the Swiss Alps linked to the Atlantic Multidecadal Oscillation. Geophys. Res. Lett. 37, L10501. http://dx.doi.org/10.1029/2010GL042616.

Huss, M., Jouvet, G., Farinotti, D., Bauder, A., 2010b. Future high-mountain hydrology: a new parameterization of glacier retreat. Hydrol. Earth Syst. Sci. 14, 815-829. http://dx.doi.org/10.5194/hess-14-815-2010.

Huss, M. Sugiyama, S., Bauder, A., Funk, M., 2007. Retreat scenarios of Unteraargletscher, Switzerland, using a combined ice-flow mass-balance model. Arctic, Antarctic Alpine Res. 39, 422-431.

Immerzeel, W., Beek, L., Konz, M., Shrestha, A., Bierkens, M., 2012. Hydrological response to climate change in a glacierized catchment in the Himalayas. Climat. Change 110, 721-736. http://dx.doi.org/10.1007/s10584-011-0143-4.

Immerzeel, W.W., van Beek, L.P.H., Bierkens, M.F.P., 2010. Climate change will affect the Asian water towers. Science 328, 1382-1385. http://dx.doi.org/10.1126/ science. 1183188

Joerg, P.C., Morsdorf, F., Zemp, M., 2012. Uncertainty assessment of multi-temporal airborne laser scanning data: a case study on an Alpine glacier. Remote Sens. Environ. 127, 118-129.

Jouvet, G., Huss, M., Funk, M., Blatter, H., 2011. Modelling the retreat of Grosser Aletschgletscher, Switzerland, in a changing climate. J. Glaciol. 57, 10331045.

Juen, I., Kaser, G., Georges, C., 2007. Modelling observed and future runoff from a glacierized tropical catchment (Cordillera Blanca, Perú). Global Planet. Change 59, 37-48.

Kaser, G., Grosshauser, M., Marzeion, B., 2010. Contribution potential of glaciers to water availability in different climate regimes. Proc. Natl. Acad. Sci. 107, 20223 20227. http://dx.doi.org/10.1073/pnas.1008162107.

Kayastha, R.B., Takeuchi, Y., Nakawo, M., Ageta, Y., 2000. Practical prediction of ice melting beneath various thickness of debris cover on Khumbu Glacier, Nepal, using a positive degree-day factor. In: Debris-Covered Glaciers, IAHS, pp. 71-82.

Klok, E.J., Oerlemans, J., 2004. Modelled climate sensitivity of the mass balance of Morteratschgletscher and its dependence on albedo parameterization. Int. J. Climatol. 23, 231-245.

Klok, E.J.L., Greuell, W., Oerlemans, J., 2003. Temporal and spatial variation of the surface albedo of Morteratschgletscher, Switzerland, as derived from 12 Landsat images. J. Glaciol. 49, 491-502.

Kobierska, F., Jonas, T., Zappa, M., Bavay, M., Magnusson, J., Bernasconi, S.M., 2013. Future runoff from a partly glacierized watershed in Central Switzerland: a twomodel approach. Adv. Water Resour. 55, 204-214.

Konz, M., Seibert, J., 2010. On the value of glacier mass balances for hydrological model calibration. J. Hydrol. 385, 238-246.
Kotlarski, S., Paul, F., Jacob, D., 2010. Forcing a distributed glacier mass balance model with the regional climate model REMO. Part I: Climate model evaluation. J. Climate 23, 1589 .

van der Linden, P., Mitchell, J., 2009. ENSEMBLES: climate change and its impacts: summary of research and results from the ENSEMBLES project. Met Office Hadley Centre, FitzRoy Road, Exeter EX1 3PB (UK).

Linsbauer, A., Paul, F., Haeberli, W., 2012. Modeling glacier thickness distribution and bed topography over entire mountain ranges with GlabTop: application of a fast and robust approach. J. Geophys. Res. 117, F03007. http://dx.doi.org/ 10.1029/2011JF002313.

Linsbauer, A., Paul, F., Machguth, H., Haeberli, W., 2013. Comparing three different methods to model scenarios of future glacier change for the entire Swiss Alps. Ann. Glaciol. 54, 241-253.

Lutz, A.F., Immerzeel, W.W., Gobiet, A., Pellicciotti, F., Bierkens, M.F.P., 2013. Comparison of climate change signals in CMIP3 and CMIP5 multi-model ensembles and implications for Central Asian glaciers. Hydrol. Earth Syst. Sci. 17, 3661-3677. http://dx.doi.org/10.5194/hess-17-3661-2013.

Machguth, $\mathrm{H}, 2008$. On the use of RCM data and gridded climatologies for regional scale glacier mass balance modeling in high mountain topography: the example of the Swiss Alps. Ph.D. thesis, University of Zurich.

Machguth, H., Eisen, O., Paul, F., Hoelzle, M., 2006a. Strong spatial variability of snow accumulation observed with helicopter-borne GPR on two adjacent Alpine glaciers. Geophys. Res. Lett. 33, L13503. http://dx.doi.org/10.1029/ 2006GL026576.

Machguth, H., Paul, F., Hoelzle, M., Haeberli, W., 2006b. Distributed glacier mass balance modelling as an important component of modern multi-level glacier monitoring. Ann. Glaciol. 43, 335-343.

Maisch, M., Wipf, A., Denneler, B., Battaglia, J., Benz, C., 2000. Die Gletscher der Schweizer Alpen, second ed., Zürich.

Mayr, E., Hagg, W., Mayer, C., Braun, L., 2013. Calibrating a spatially distributed conceptual hydrological model using runoff, annual mass balance and winter mass balance. J. Hydrol. 478, 40-49.

Nakicenovic, N. et al., 2000. Special Report on Emissions Scenarios: A Special Report of Working Group III of the Intergovernmental Panel on Climate Change. Cambridge University Press, Cambridge, U.K., p. 599.

Nash, J.E., Sutcliffe, J.V., 1970. River flow forecasting through conceptual models. J. Hydrol. 10, 282-290.

Nicholson, L., Benn, D.I., 2006. Calculating ice melt beneath a debris layer using meteorological data. J. Glaciol. 52, 463-470.

Oerlemans, J., 2001. Glaciers and Climate Change. A.A. Balkema Publishers.

Oerlemans, J., Giessen, R.H., van den Broeke, M.R., 2009. Retreating alpine glaciers: increased melt rates due to accumulation of dust (Vadret da Morteratsch, Switzerland). J. Glaciol. 55, 729-736.

Oerlemans, J., Knap, W.H., 1998. A 1 year record of global radiation and albedo in the ablation zone of Morteratschgletscher, Switzerland. J. Glaciol. 44, 231-238.

Paul, F., Maisch, M., Rothenbuehler, C., Hoelzle, M., Haeberli, W., 2007. Calculation and visualisation of future glacier extent in the Swiss Alps by means of hypsographic modelling. Global Planet. Change 55, 343-357.

Pellicciotti, F., Brock, B., Strasser, U., Burlando, P., Funk, M., Corripio, J., 2005. An enhanced temperature-index glacier melt model including the shortwave radiation balance: development and testing for Haut Glacier d'Arolla, Switzerland. J. Glaciol. 51, 573-587.

Radić, V., Hock, R., 2006. Modeling future glacier mass balance and volume changes using ERA-40 reanalysis and climate models: a sensitivity study at Storglaciären, Sweden. J. Geophys. Res. 111, F03003. http://dx.doi.org/ 10.1029/2005JF000440.

Ragettli, S., Pellicciotti, F., Bordoy, R., Immerzeel, W.W., 2013. Sources of uncertainty in modeling the glaciohydrological response of a Karakoram watershed to climate change. Water Resour. Res.. http://dx.doi.org/10.1002/wrcr.20450, n/an/a.

Reid, T.D., Brock, B.W., 2010. An energy-balance model for debris-covered glaciers including heat conduction through the debris layer. J. Glaciol. 56, 903-916.

Rohrer, M., 1989. Determination of the transition air temperature from snow to rain and intensity of precipitation. In: WMO IASH ETH International Workshop on Precipitation Measurement, pp. 475-582.

Rössler, O., Diekkrüger, B., Löffler, J., 2012. Potential drought stress in a Swiss mountain catchment - ensemble forecasting of high mountain soil moisture reveals a drastic decrease, despite major uncertainties. Water Resour. Res. 48, W04521. http://dx.doi.org/10.1029/2011WR011188.

Salzmann, N., Frei, C. Vidale, P. Hoelzle, M., 2007. The application of regional climate model output for the simulation of high-mountain permafrost scenarios. Global Planet. Change 56, 188-202.

Salzmann, N., Machguth, H., Linsbauer, A., 2012. The Swiss Alpine glaciers' response to the global ' 2 degrC air temperature target'. Environ. Res. Lett. 7, 044001.

Schaefli, B., Hingray, B., Niggli, M., Musy, A., 2005. A conceptual glacio-hydrological model for high mountainous catchments. Hydrol. Earth Syst. Sci. 9, 95-109.

Schaefli, B., Huss, M., 2011. Integrating point glacier mass balance observations into hydrologic model identification. Hydrol. Earth Syst. Sci. 15, 1227-1241. http:// dx.doi.org/10.5194/hess-15-1227-2011.

Scherler, D., Bookhagen, B., Strecker, M.R., 2011. Spatially variable response of Himalayan glaciers to climate change affected by debris cover. Nat. Geosci. 4 , 156-159. http://dx.doi.org/10.1038/ngeo1068.

Sold, L., Huss, M., Andereggen, H., Joerg, P.C., Hoelzle, M., Zemp, M., 2013. Methodological approaches to infer end-of-winter snow distribution on alpine glaciers. J. Glaciol. 59, 1047-1059. 
Stahl, K., Moore, R.D., Shea, J.M., Hutchinson, D., Cannon, A.J., 2008. Coupled modelling of glacier and streamflow response to future climate scenarios. Water Resour. Res. 44, W02422. http://dx.doi.org/10.1029/2007WR005956.

Tarboton, D.G., Chowdhury, T.G., Jackson, T.H., 1995. A spatially distributed energy balance snowmelt model. In: Tonnessen, K.A., Williams, M.W., Tranter, M. (Eds.), Biogeochemistry of Seasonally Snow-covered Catchments, Proceedings of a Boulder Symposium, IAHS Publication Number 228, pp. 141-155.

Uhlmann, B., Jordan, F., Beniston, M., 2013a. Modelling runoff in a Swiss glacierized catchment - Part I: Methodology and application in the Findelen basin under a long-lasting stable climate. Int. J. Climatol. 33, 1293-1300.

Uhlmann, B., Jordan, F., Beniston, M., 2013b. Modelling runoff in a Swiss glacierized catchment - Part II: Daily discharge and glacier evolution in the Findelen basin in a progressively warmer climate. Int. J. Climatol. 33, 1301-1307.
Verbunt, M., Gurtz, J., Jasper, K., Lang, H., Warmerdam, P., Zappa, M., 2003. The hydrological role of snow and glaciers in alpine river basins and their distributed modeling. J. Hydrol. 282, 36-55.

Viviroli, D, et al., 2011. Climate change and mountain water resources: overview and recommendations for research, management and politics. Hydrol. Earth Syst. Sci. 15, 471-504.

Weber, M., Braun, L., Mauser, W., Prasch, M., 2010. Contribution of rain, snow- and icemelt in the upper Danube today and in the future. Geogr. Fis. Dinam. Quat. $33,221-230$.

Wild, M., Schmucki, E., 2011. Assessment of global dimming and brightening in IPCC-AR4/CMIP3 models and ERA40. Climate Dynam. 37, 1671-1688.

Xu, J., Grumbine, R.E., Shrestha, A., Eriksson, M., Yang, X., Wang, Y., Wilkes, A., 2009. The melting Himalayas: cascading effects of climate change on water biodiversity, and livelihoods. Conserv. Biol. 23, 520-530. 